Molecules 2010, 15, 9230-9251; doi:10.3390/molecules15129230

OPEN ACCESS

molecules

ISSN 1420-3049

www.mdpi.com/journal/molecules

Review

\title{
[2+2+2] Cycloaddition Reactions of Macrocyclic Systems Catalyzed by Transition Metals. A Review
}

\author{
Anna Pla-Quintana and Anna Roglans* \\ Departament de Química, Universitat de Girona, E-17071-Girona, Spain \\ * Author to whom correspondence should be addressed; E-Mail: anna.roglans@udg.edu.
}

Received: 24 November 2010; in revised form: 10 December 2010 / Accepted: 14 December 2010 /

Published: 15 December 2010

\begin{abstract}
Polyalkyne and enediyne azamacrocycles are prepared from arenesulfonamides and various alkyne and alkene derivatives either under basic or neutral conditions. The new family of macrocyclic substrates is tested in the $[2+2+2]$ cycloaddition reaction. Several catalysts are used for the cycloisomerization reaction, and their enantioinduction is evaluated as appropriate. The effect of the structural features of the macrocycles, namely the ring size, substituents in precise positions and the number and type of unsaturations, on the $[2+2+2]$ cycloaddition reaction has also been studied.
\end{abstract}

Keywords: azamacrocycles; alkynes; alkenes; [2+2+2] cycloadditions; transition metals

\section{Introduction}

A highly reliable and atom-economical method for the synthesis of polysubstituted benzene derivatives is the transition-metal-catalyzed [2+2+2] cycloaddition of three alkynes [1-13]. Completely intramolecular reactions are particularly interesting as they provide complex polycyclic systems in a single synthetic operation (Equation 1, Scheme 1) [14-26]. Furthermore, if the three alkynes form part of a closed system, i.e. a macrocycle, fused tetracycles may easily be obtained (Equation 2, Scheme 1). The $[2+2+2]$ cycloaddition is not a reaction that is exclusive for triple bonds, as it can also take place between two acetylenes and one alkene giving rise to cyclohexadienes. Given this, the same concept could be applied for the completely intramolecular [2+2+2] cycloaddition of enediynes to afford fused polysubstituted cyclohexadienes (Equation 3, Scheme 1) [27-33]. 
Scheme 1. General representation of intramolecular [2+2+2] cycloadditions of triynes and enediynes.

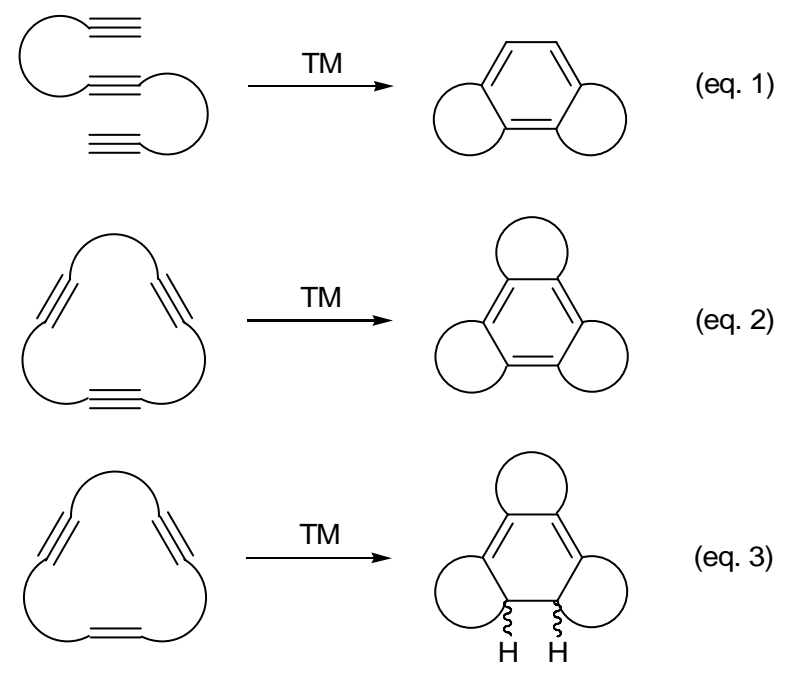

Despite this strategy being synthetically attractive, hardly any cyclotrimerization reactions of macrocyclic systems containing triple bonds have been reported. Vollhardt, in an article published in 1976 [34], prepared 1,5,9-cyclododecatriyne, which proved to be inert in the presence of light, high pressure and temperature, acidic conditions, and the $\mathrm{CpCo}(\mathrm{CO})_{2}$ catalyst. The cycloisomerization of cyclotriynes into tricyclic benzene derivatives has only been reported in two silicon-tethered macrocycles by Sakurai et al. in low yields and in the presence of other $\pi$ electron systems [35-37] (Scheme 2).

Scheme 2. Intramolecular cyclization of macrocyclic polyacetylenes tethered by disiloxane and disilmethylene bridges.

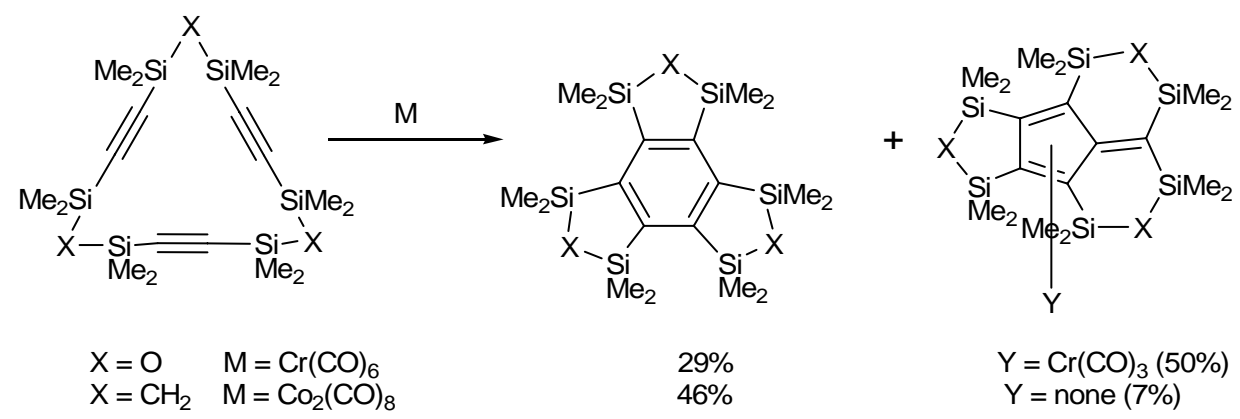

In recent years our group has been interested in the synthesis and applications of polyalkyne and enediyne azamacrocyclic systems [38-44]. Early on we observed that the [2+2+2] cycloisomerization of the closed derivatives could easily result in highly functionalized tetracyclic fused structures in onepot and atom-economical process. In addition, since our macrocyclic systems contain nitrogen atoms in the tethers between unsaturations, their $[2+2+2]$ cycloaddition reaction opens the door to the construction of polycyclic azaheterocycles.

In this review we present our work in this field, starting with highly efficient synthetic strategies towards several polyunsaturated azamacrocycles and then look at their cycloaddition reactions catalyzed by transition metals to afford fused polycyclic structures. 


\section{Synthesis of Polyunsaturated Azamacrocycles}

\subsection{Preparation of tri-, tetra-, and pentaacetylenic azamacrocycles}

In a previous project in which we participated, synthetic routes towards 15 -membered triazatrienic macrocycles were optimized $[45,46]$. This was our source of inspiration towards the synthesis of the array of triacetylenic macrocycles that have been prepared for testing in the $[2+2+2]$ cycloaddition reaction, shown in Figure 1.

Figure 1. Triacetylenic azamacrocycles.

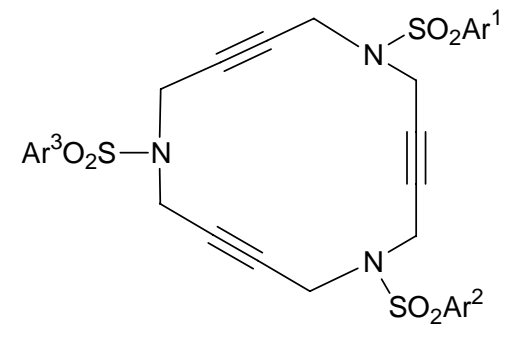

1a $\mathrm{Ar}^{1}=\mathrm{Ar}^{2}=\mathrm{Ar}^{3}=4-\mathrm{MeC}_{6} \mathrm{H}_{4}$

1b $\operatorname{Ar}^{1}=\mathrm{Ar}^{2}=\mathrm{Ar}^{3}=2,4,6-\left({ }^{\prime} \mathrm{Pr}\right)_{3} \mathrm{C}_{6} \mathrm{H}_{2}-$

1c $\operatorname{Ar}^{1}=\mathrm{Ar}^{2}=\mathrm{Ar}^{3}=$ ferrocenyl-

1d $\mathrm{Ar}^{1}=\mathrm{Ar}^{2}=4-\mathrm{MeC}_{6} \mathrm{H}_{4^{-}}, \mathrm{Ar}^{3}=$ ferrocenyl-

1e $\mathrm{Ar}^{1}=4-\mathrm{MeC}_{6} \mathrm{H}_{4-}, \mathrm{Ar}^{2}=$ ferrocenyl-, $\mathrm{Ar}^{3}=4-$ vinylC $_{6} \mathrm{H}_{4}-$

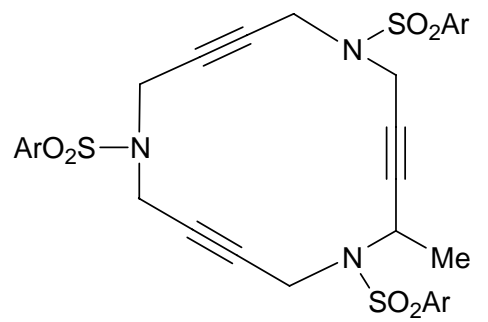

$2 \mathrm{Ar}=4-\mathrm{MeC}_{6} \mathrm{H}_{4}$

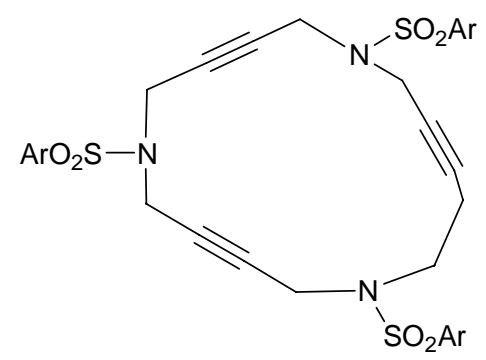

$3 \mathrm{Ar}=2,4,6-\left({ }^{\mathrm{i}} \mathrm{Pr}\right)_{3} \mathrm{C}_{6} \mathrm{H}_{2}^{-}$

Different 15-membered azamacrocycles of type $\mathbf{1}$ were prepared by varying the nature of the arylsulfonamide to confer, enhance or modulate certain properties of the macrocycles. As an example, 4-methylphenyl aryl groups in the sulfonamide moiety give crystallinity to the macrocycles permitting $\mathrm{X}$-ray diffraction analysis. Ferrocenyl groups confer an orange colour to the compounds facilitating their purification by column chromatography. The three isopropyl chains in the 2,4,6triisopropylsulfonyl moiety improve solubility in standard organic solvents.

The synthesis of these 15-membered macrocycles is quite straightforward using sulfonamide alkylation reactions combined with N-tert-butyloxycarbonyl (Boc) protection/deprotection to direct the reaction to the desired product (control of mono- and dialkylation). The starting materials are commercially available arylsulfonamides and various 1,4-dihalo-2-butynes or derivatives. The synthetic routes varied depending on whether the arylsulfonamides contained in the azamacrocycle were the same or different. For macrocycles 1a-d, which contain three identical arylsulfonamides (1a [38], 1b [39], and 1c [39]) or two identical and one different arylsulfonamide (1d [38]), the synthetic pathways are represented in Scheme 3. The synthesis started with arylsulfonamides 4a-c which were protected by Boc to give the corresponding derivatives 5a-c. Boc-protected sulfonamides 5a-c were treated either with dibromide $\mathbf{6}$, dichloride $\mathbf{7}$ or dimesylate 8 (4 equiv.) to afford derivatives 9a-c.

The choice between 6, 7 or $\mathbf{8}$ depends on several factors. Firstly, on their availability: whereas the chloro derivative 7 is commercially available, bromo derivative 6 and dimesylate 8 have to be specially prepared. Secondly, the yield of the reaction varies depending on the leaving group: as expected, best results are invariably obtained with bromo derivative 6 rather than the chloro derivative. The dimesylate $\mathbf{8}$ is quite effective, but thick salts are sometimes formed requiring mechanical stirring 
of the reaction mixtures. Finally, the powerful irritating properties of dibromo derivative $\mathbf{6}$ can cause a skin allergy and so extreme precaution has to be taken in the manipulation of both the product itself and associated waste products.

Scheme 3. Synthesis of macrocycles 1a, 1b, 1c and 1d.

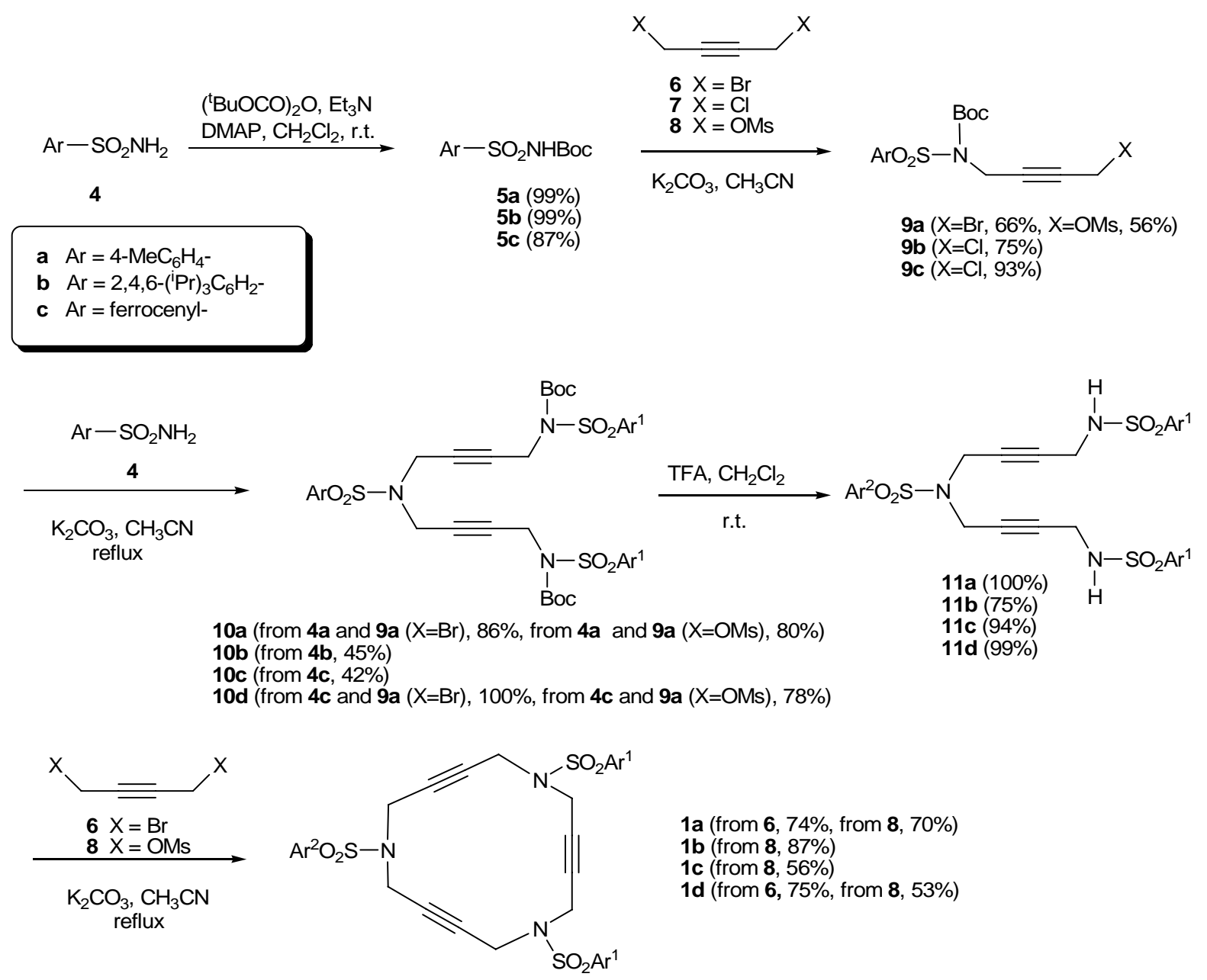

Once the Boc-protected arylsulfonamide was monoalkylated, the synthetic route continued with condensation of $\mathbf{9}$ with arylsulfonamides $\mathbf{4}$ to lead to 10, which gave trisulfonamides $\mathbf{1 1}$ after deprotection. Final ring closure was achieved by treatment of $\mathbf{1 1}$ again by using one equivalent of either dibromide 6 or dimesylate 8. Ring closure with 1,4-dichloro-2-butyne gave extremely low yields and so was not normally undertaken (Scheme 3).

The synthesis of macrocycle 1e [39] containing three different aryl units required a modified pathway and was prepared as outlined in Scheme 4. Condensation of bromosulfonamide derivative 9a with one equivalent of Boc-protected ferrocenylsulfonamide $\mathbf{5 c}$ using potassium carbonate in refluxing acetonitrile led to a 76\% yield of compound 12. The elimination of Boc groups in compound 12 and subsequent treatment with an excess of 1,4-bis(methanesulfonyloxy)-2-butyne 8 resulted in the isolation of derivative $\mathbf{1 4}$ with a $67 \%$ yield. The reaction of 14 with 4 -vinylbenzenesulfonamide $\mathbf{4 d}$ was straightforward and led to the formation of macrocycle 1e featuring three different aryl substituents. 
Scheme 4. Synthesis of macrocycle 1e.

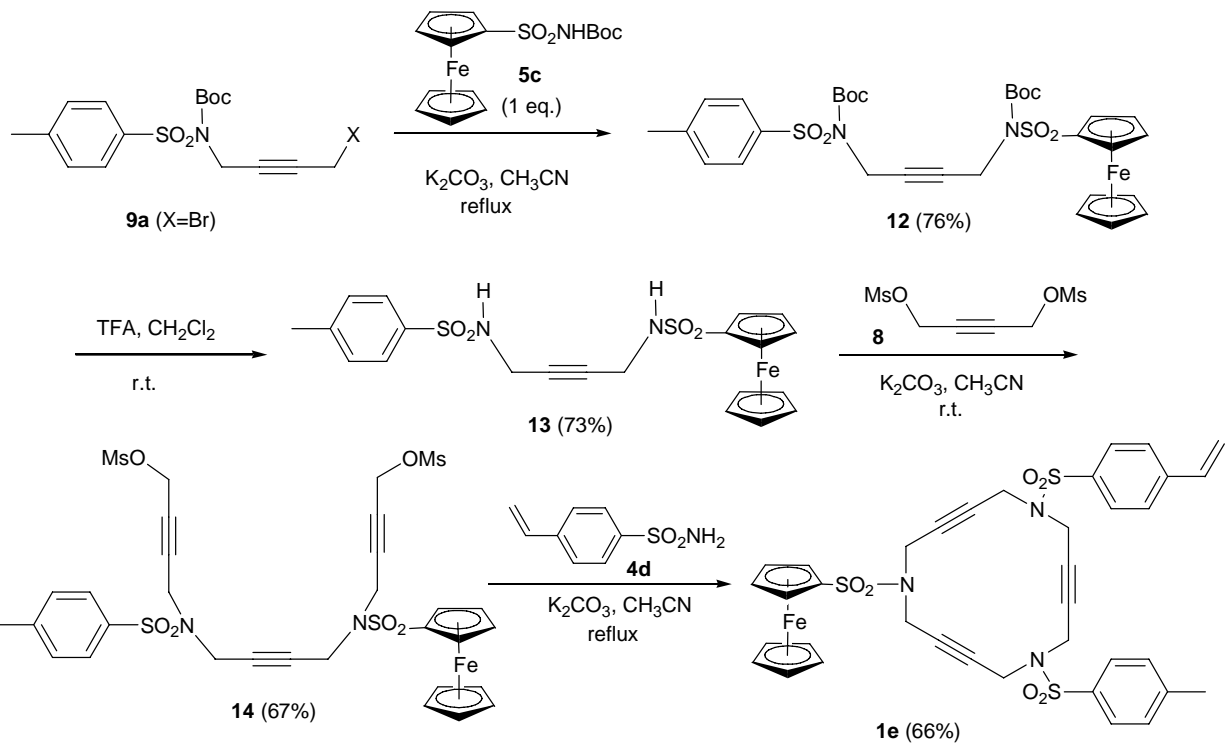

Furthermore, a 15-membered azamacrocycle containing a methyl group in one of the propargylic positions (2) [41] and a 16-membered macrocycle (3) [41] (see Figure 1) were also prepared following the synthetic pathway outlined in Scheme 5.

Scheme 5. Synthesis of macrocycles 2 and 3.

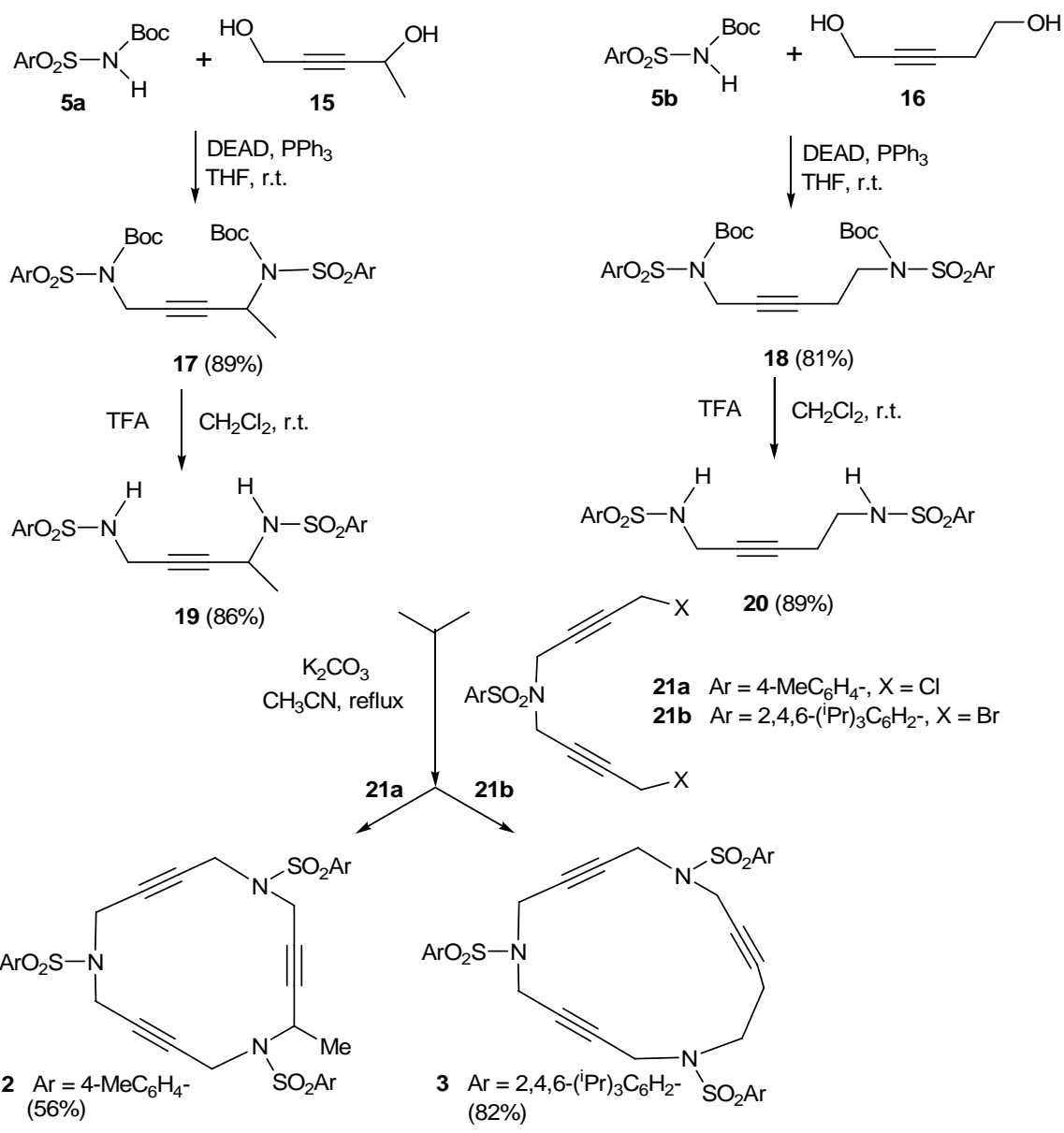


The main difference between these syntheses and those described above is the use of the Mitsunobu reaction. The whole synthesis started with the preparation of compounds $\mathbf{1 7}$ and $\mathbf{1 8}$ by alkylation of Boc-protected sulfonamides $\mathbf{5 a}$ and $\mathbf{5 b}$ with 0.5 equivalents of the corresponding diol 2-pentyne-1,4diol 15 or 2-pentyne-1,5-diol 16 under Mitsunobu reaction conditions. This made it possible to work with the diol derivatives to introduce the first alkyne chain under neutral alkylation conditions and avoided the elimination reactions that can take place in basic alkylation conditions in haloderivatives of compound 16. The elimination of the Boc groups in compounds $\mathbf{1 7}$ and $\mathbf{1 8}$ and the subsequent treatment with one equivalent of diacetylenic derivative 21a and 21b [47] respectively resulted in the isolation of macrocyles $\mathbf{2}$ and $\mathbf{3}$ with good overall yields.

The family of N-containing polyalkyne macrocycles was extended to higher order macrocycles, namely compounds of type 22 and 23 containing 4 or 5 triple bonds (and N) respectively (Figure 2).

Figure 2. Tetra- and pentaacetylenic azamacrocycles.

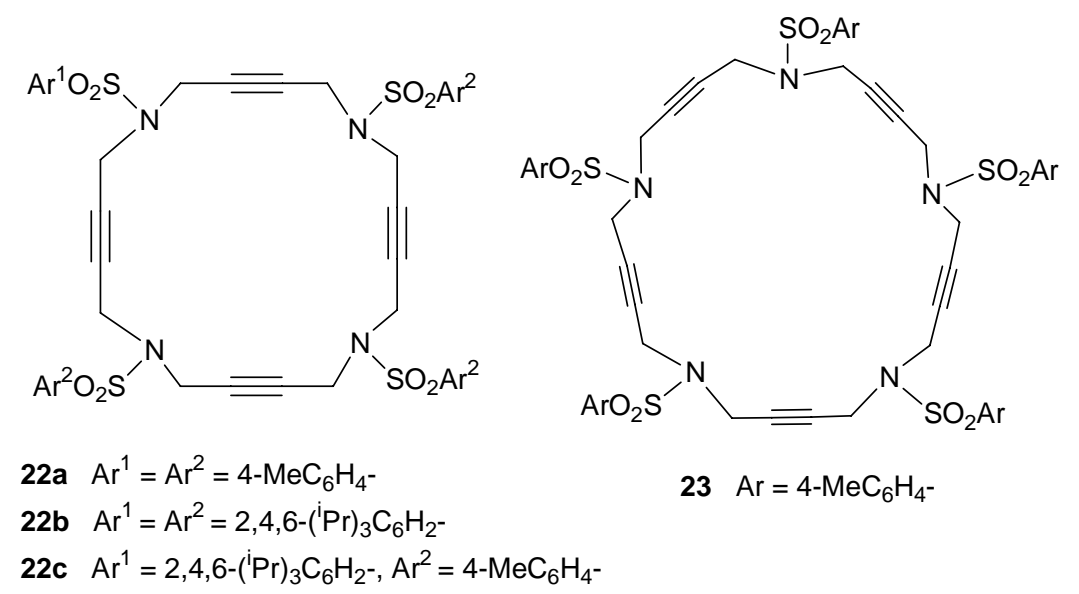

The 20 and 25-membered macrocycles 22 [43] and 23 [43] were prepared following the synthetic pathway outlined in Scheme 6. One of the variants of macrocycles 22 is the nature of the aryl units on the periphery, analogously to the situation commented regarding the 15 -membered macrocycles. Firstly, two macrocycles, 22a and 23, containing the same aryl unit, $p$-tolylsulfonamide, attached to all of the sulfonamides were prepared. The whole synthesis started with the preparation of compound 25 from a reaction of Boc-protected p-tolylsulfonamide 5a and 0.5 equiv. of 2-butyne-1,4-diol 24 under Mitsunobu reaction conditions. The elimination of the Boc groups in compound 25 and the subsequent treatment with two equiv. of bromo derivative 9a resulted in the isolation of compound 27 with an $80 \%$ yield. The elimination of the Boc groups with the same reaction conditions as before (TFA in $\mathrm{CH}_{2} \mathrm{Cl}_{2}$ ) gave intermediate 28. Compound 28, which already contains three acetylenic chains and four identical sulfonamide units, was the key intermediate for the preparation of both macrocycles. Cyclization of 28 with 1,4-dibromo-2-butyne in the presence of $\mathrm{K}_{2} \mathrm{CO}_{3}$ as a base afforded a $60 \%$ yield of macrocycle 22a. When intermediate $\mathbf{2 8}$ was condensed with the dichloro derivative 21a, the 25membered pentaacetylenic macrocycle 23 was obtained in almost quantitative yield. Macrocycles 22b and 22c containing 2,4,6-triisopropylphenyl in all or some of the arylsulfonamide moieties, respectively, were prepared by an alternative synthetic route (Scheme 6). Condensation between dibromo derivative 21b and trisulfonamide 11a afforded a 96\% yield of macrocycle 22c. Reaction of 11b with 21b gave macrocycle 22b containing four units of 2,4,6-triisopropylphenyl. 
Scheme 6. Synthesis of macrocycles 22a-c and 23.
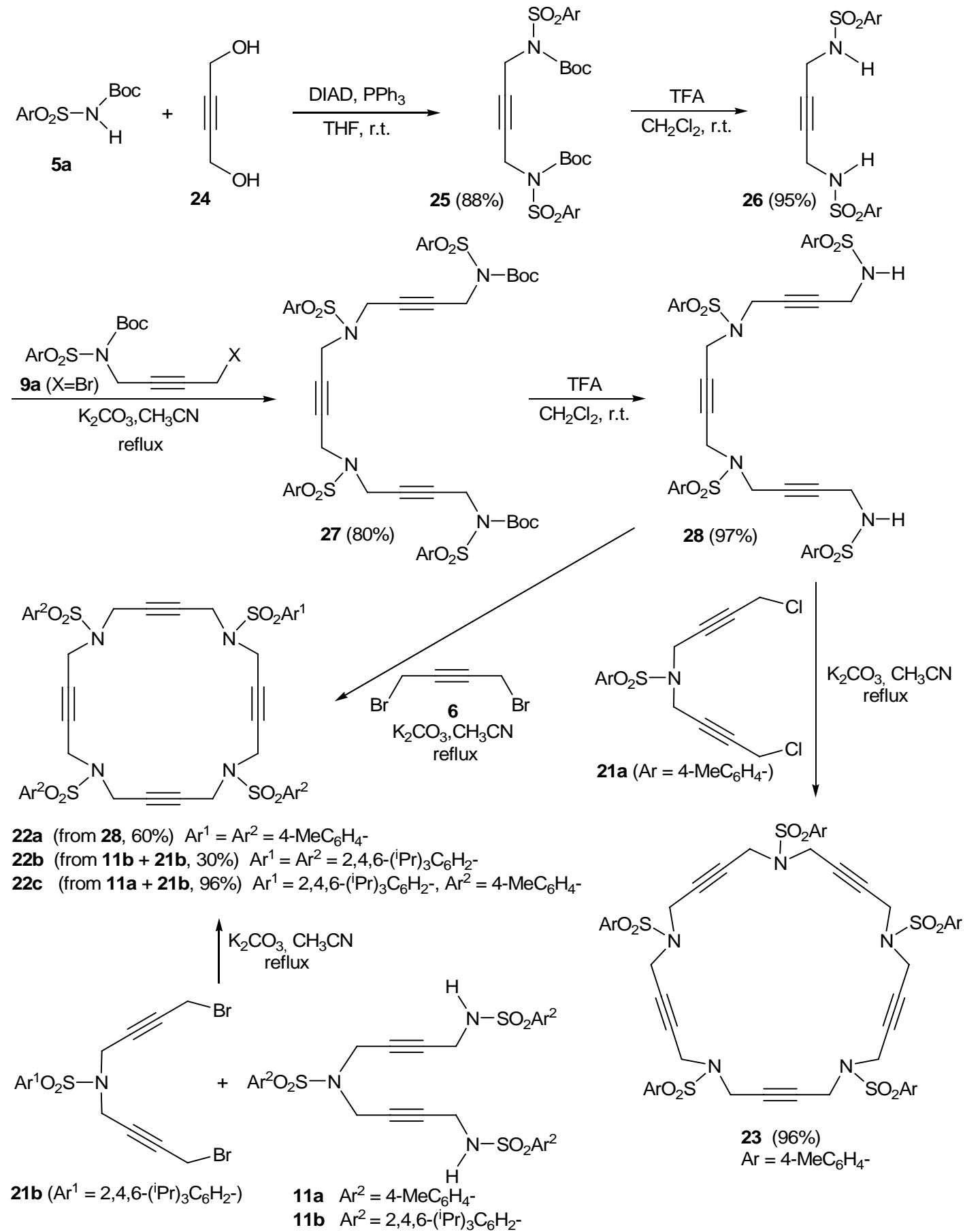

\subsection{Preparation of enediyne azamacrocycles}

Since the $[2+2+2]$ cycloaddition can also take place between two alkynes and one alkene as $\mathrm{C}_{2}$ sources, we were also interested in preparing enediyne macrocycles. The enediyne macrocycles which were prepared to test in the $[2+2+2]$ cycloaddition reaction are represented in Figure 3. Structural variations were introduced in order to have double bonds of different stereochemistry (trans 29, 31, 33, 35 or cis 30, 32, 34), a substituent on the double bond ( $\mathrm{Ph}, 31$ and 32), and macrocycles of different order (15-membered 29-32, 16-membered 33-34 and 17-membered 35 macrocycles). 
Figure 3. Enediyne azamacrocycles.

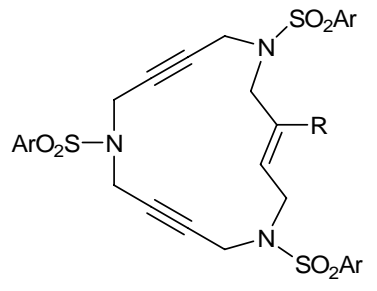

29a $\left(\mathrm{R}=\mathrm{H}, \mathrm{Ar}=4-\mathrm{MeC}_{6} \mathrm{H}_{4}-\right)$ 29b $\left(\mathrm{R}=\mathrm{H}, \mathrm{Ar}=2,4,6-\left({ }^{\mathrm{P} r}\right)_{3} \mathrm{C}_{6} \mathrm{H}_{2^{-}}\right)$

$31\left(\mathrm{R}=\mathrm{Ph}, \mathrm{Ar}=4-\mathrm{MeC}_{6} \mathrm{H}_{4^{-}}\right)$

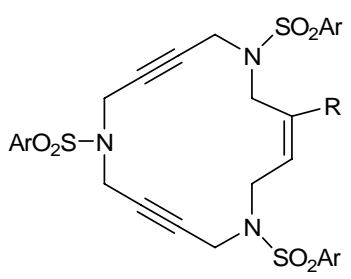

30a $\left(\mathrm{R}=\mathrm{H}, \mathrm{Ar}=4-\mathrm{MeC}_{6} \mathrm{H}_{4}-\right)$

30b $\left(\mathrm{R}=\mathrm{H}, \mathrm{Ar}=2,4,6-\left({ }^{\mathrm{P}} \mathrm{Pr}\right)_{3} \mathrm{C}_{6} \mathrm{H}_{2^{-}}\right)$

$32\left(\mathrm{R}=\mathrm{Ph}, \mathrm{Ar}=4-\mathrm{MeC}_{6} \mathrm{H}_{4^{-}}\right)$

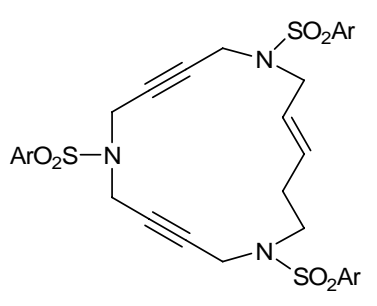

$33\left(\mathrm{Ar}=4-\mathrm{MeC}_{6} \mathrm{H}_{4}-\right)$

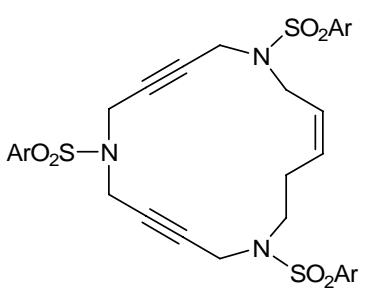

$34\left(\mathrm{Ar}=4-\mathrm{MeC}_{6} \mathrm{H}_{4-}-\right)$

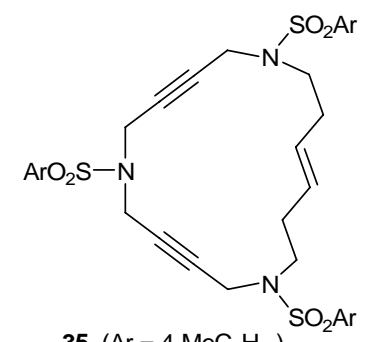

$35\left(\mathrm{Ar}=4-\mathrm{MeC}_{6} \mathrm{H}_{4^{-}}\right)$

The 15-membered enediyne macrocycles 29 [39], 30 [39], 31 [41] and 32 [41] were prepared starting from a common intermediate, the trisulfonamide derivative 11, which reacted with the corresponding dibromo allylic derivative to afford the closed system (Scheme 7). This intermediate 11 contains either 4-methylphenyl (11a) or 2,4,6-triisopropylphenyl (11b) as the aryl units. Ring closure was achieved by treatment of $\mathbf{1 1}$ with one equivalent of either $(E)$ or (Z)-1,4-dibromo-2-butene derivatives 36-39 in the presence of $\mathrm{K}_{2} \mathrm{CO}_{3}$ in refluxing acetonitrile.

Scheme 7. Synthesis of 15-membered enediyne macrocycles 29-32.

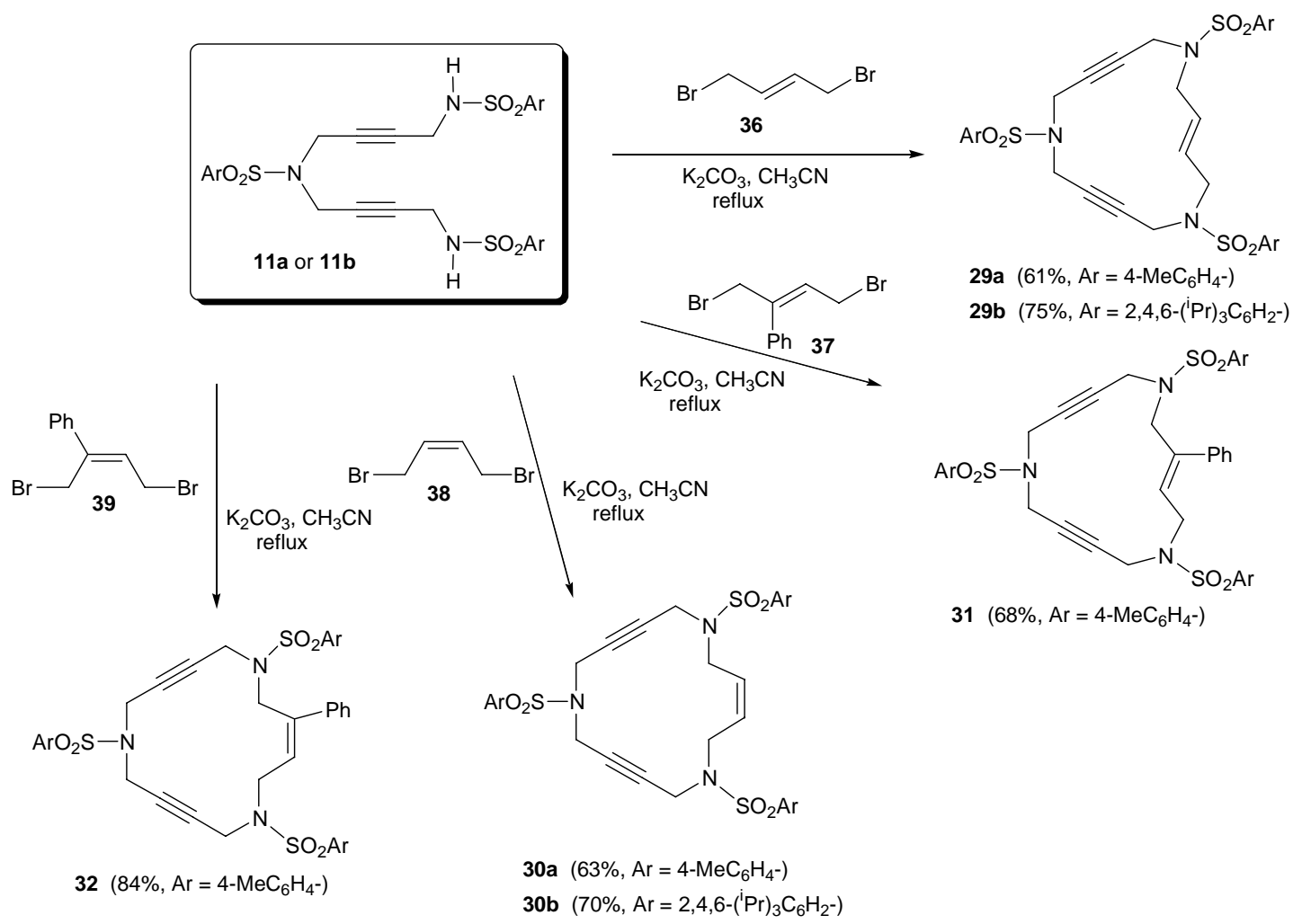


In the case of enediynes 33-35 [41], in order to avoid $\beta$-elimination of the homoallylic position of the corresponding dibromo derivative in the ring closure when treated with base $\left(\mathrm{K}_{2} \mathrm{CO}_{3}\right)$, the synthetic pathway applied was similar to the one in Scheme 5 for triacetylenic macrocycles $\mathbf{2}$ and $\mathbf{3}$ (Scheme 8). We took Mitsunobu reaction conditions as the key to this pathway. The alkylation of N-Boc protected sulfonamide 5a with diols $\mathbf{4 0}$ and $\mathbf{4 1}$ under neutral Mitsunobu conditions afforded derivatives $\mathbf{4 2}$ and 43 in excellent yields. After removal of the Boc groups with trifluoroacetic acid, ring closure was achieved by reaction with dibromo 21c to give azamacrocycles 33-35. Commercially available diol 40 was a 4.5:1 mixture of trans and cis isomers and all the reactions of Scheme 8 were performed with this inseparable mixture. In the last step, macrocycles 33 (trans) and 34 (cis) were separated by column chromatography. The trans was obtained with a $63 \%$ yield and the cis with a $13 \%$ yield.

Scheme 8. Synthesis of 16- and 17-membered enediyne macrocycles 33, 34 and 35.
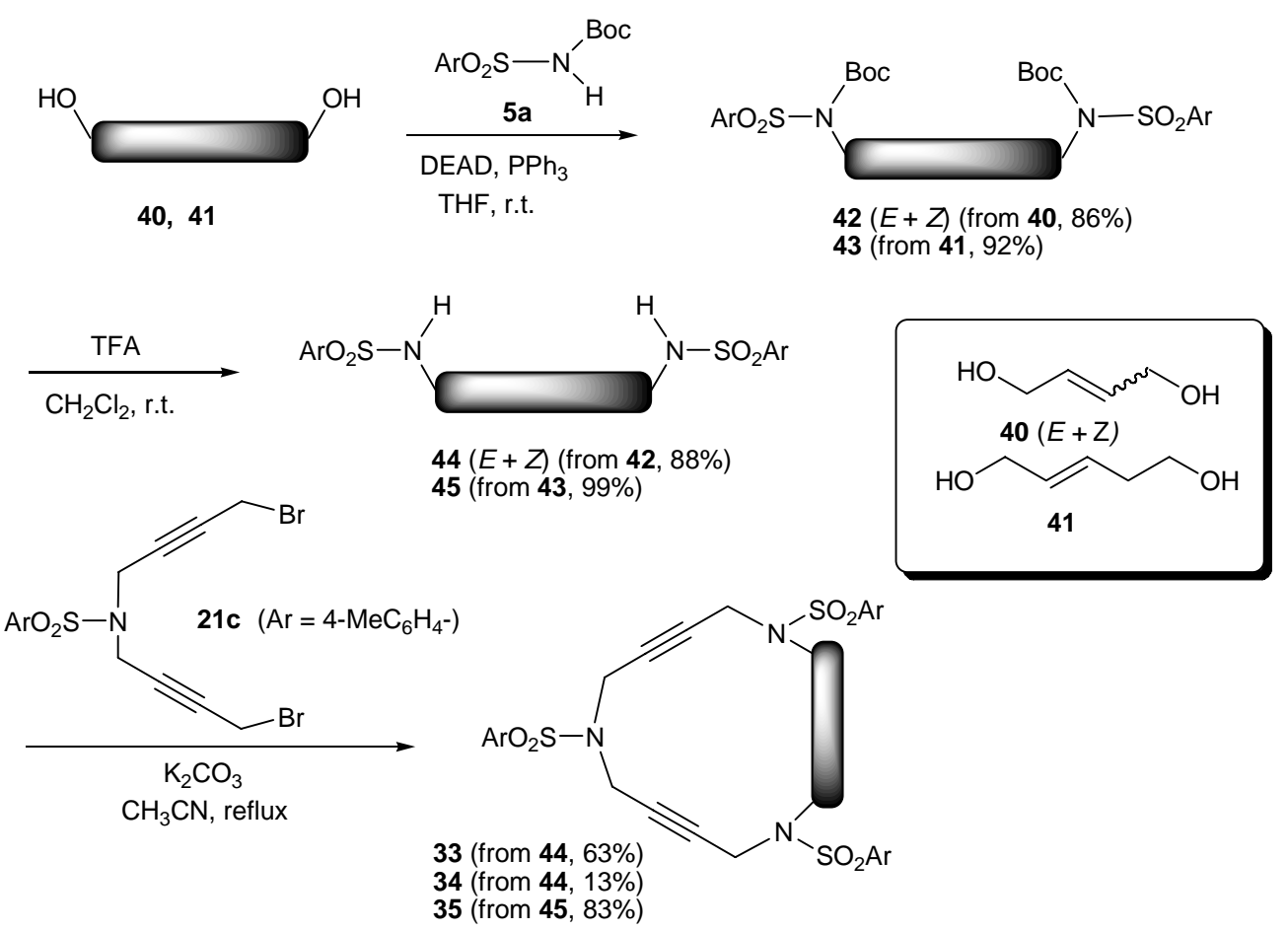

\section{3. [2+2+2] Cycloaddition Reactions}

\subsection{Cycloaddition reactions of tri-, tetra-, and pentaacetylenic azamacrocycles}

Our investigation into cycloisomerization in the macrocyclic systems cited here began at a time of burgeoning interest in [2+2+2] cycloaddition reactions [1-13]. Our first aim was to test some of the metals that had proved to be more effective for related intra- and intermolecular cycloadditions in a macrocyclic scaffold (Table 1). Palladium complex $\mathrm{Pd}\left(\mathrm{PPh}_{3}\right)_{4}$ was the first metal of choice $[48,49]$. When 1a was treated with catalytic amounts of $\mathrm{Pd}\left(\mathrm{PPh}_{3}\right)_{4}$, the reaction failed and it was necessary to use 1.1 equiv of $\mathrm{Pd}$ in refluxing toluene to obtain triazaindane 46a in 54\% yield (Entry 1, Table 1). If the reaction was run in $\mathrm{THF}$ and at room temperature, the macrocycle formed a highly stable $\operatorname{Pd}(0)$ complex in which the three triple bonds of 1a were responsible for the complexation [38]. The same 
behaviour was observed for macrocycles 1b-1e, all requiring stoichiometric quantities of palladium to afford cycloaddition products in moderate yields (Entries 2-5, Table 1).

Table 1. Cycloisomerization reactions of macrocycles 1, 2, and 3.

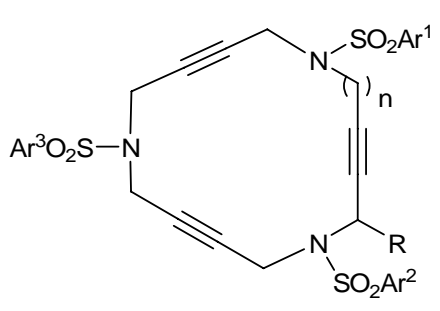

1a-e $(n=1, R=H)$

$2(\mathrm{n}=1, \mathrm{R}=\mathrm{Me})$

$3(n=2, R=H)$

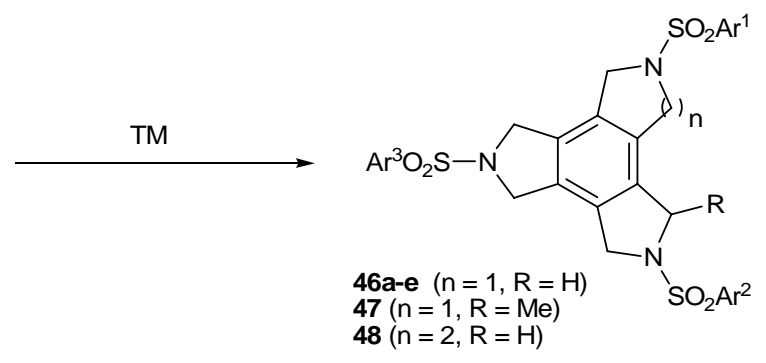

$47(n=1, R=M e)$

$48(n=2, R=H)$

\begin{tabular}{|c|c|c|c|c|c|c|}
\hline Entry & MCC & $\begin{array}{l}\text { Catalyst } \\
(\% \text { molar })\end{array}$ & Reaction conditions & Product & $\begin{array}{l}\text { Yield } \\
(\%)\end{array}$ & Ref. \\
\hline 1 & $1 \mathrm{a}$ & $\mathrm{Pd}\left(\mathrm{PPh}_{3}\right)_{4}(110)$ & toluene, reflux, $22 \mathrm{~h}$ & $46 a$ & 54 & [38] \\
\hline 2 & $1 b$ & $\mathrm{Pd}\left(\mathrm{PPh}_{3}\right)_{4}(110)$ & toluene, reflux, $24 \mathrm{~h}$ & 46b & 54 & [39] \\
\hline 3 & 1c & $\mathrm{Pd}\left(\mathrm{PPh}_{3}\right)_{4}(110)$ & toluene, reflux, $24 \mathrm{~h}$ & $46 c$ & 65 & [39] \\
\hline 4 & 1d & $\mathrm{Pd}\left(\mathrm{PPh}_{3}\right)_{4}(110)$ & toluene, reflux, $24 \mathrm{~h}$ & 46d & 54 & [39] \\
\hline 5 & $1 \mathrm{e}$ & $\mathrm{Pd}\left(\mathrm{PPh}_{3}\right)_{4}(110)$ & toluene, reflux, $24 \mathrm{~h}$ & $46 e$ & 45 & [39] \\
\hline 6 & $1 b$ & $\mathrm{CpCo}(\mathrm{CO})_{2}(5)$ & decane, $140^{\circ} \mathrm{C}, 3.5 \mathrm{~h}$ & $46 b$ & 44 & [39] \\
\hline 7 & $1 b$ & $\mathrm{CpCo}(\mathrm{CO})_{2}(100)$ & decane, $140^{\circ} \mathrm{C}, 1 \mathrm{~h}$ & 46b & 88 & [39] \\
\hline 8 & $1 b$ & Grubbs' cat. $^{\text {a }}(7)$ & toluene, reflux, $22 \mathrm{~h}$ & $46 b$ & 36 & [39] \\
\hline 9 & 1d & Grubbs' cat. ${ }^{a}(7)$ & toluene, reflux, $22 \mathrm{~h}$ & 46d & 42 & [39] \\
\hline 10 & $1 b$ & Grubbs' cat. ${ }^{a}(20)$ & toluene, reflux, $22 \mathrm{~h}$ & $46 b$ & 36 & [39] \\
\hline 11 & $1 a$ & $\mathrm{RhCl}(\mathrm{CO})\left(\mathrm{PPh}_{3}\right)_{2}(5)$ & toluene, $65^{\circ} \mathrm{C}, 24 \mathrm{~h}$ & $46 a$ & 88 & [39] \\
\hline 12 & $1 b$ & $\mathrm{RhCl}(\mathrm{CO})\left(\mathrm{PPh}_{3}\right)_{2}(5)$ & toluene, $65^{\circ} \mathrm{C}, 18 \mathrm{~h}$ & $46 b$ & 96 & [39] \\
\hline 13 & 1d & $\mathrm{RhCl}(\mathrm{CO})\left(\mathrm{PPh}_{3}\right)_{2}(5)$ & toluene, $65^{\circ} \mathrm{C}, 24 \mathrm{~h}$ & 46d & 89 & [39] \\
\hline 14 & $1 \mathbf{b}$ & $\mathrm{RhCl}(\mathrm{CO})\left(\mathrm{PPh}_{3}\right)_{2}(1)$ & toluene, $65^{\circ} \mathrm{C}, 72 \mathrm{~h}$ & $46 \mathrm{~b}$ & 80 & [39] \\
\hline 15 & 1a & $\operatorname{RhCl}\left(\mathrm{PPh}_{3}\right)_{3}(10)$ & toluene, r.t., $1.5 \mathrm{~h}$ & $46 a$ & 84 & b \\
\hline 16 & 2 & $\mathrm{RhCl}\left(\mathrm{PPh}_{3}\right)_{3}(10)$ & toluene, r.t., $26 \mathrm{~h}$ & 47 & 91 & $\mathrm{~b}$ \\
\hline 17 & 2 & $\mathrm{RhCl}\left(\mathrm{PPh}_{3}\right)_{3}(10)$ & toluene, $60^{\circ} \mathrm{C}, 24 \mathrm{~h}$ & 47 & 99 & [41] \\
\hline 18 & 3 & $\mathrm{RhCl}\left(\mathrm{PPh}_{3}\right)_{3}(5)$ & toluene, $90^{\circ} \mathrm{C}, 28 \mathrm{~h}$ & 48 & 81 & [41] \\
\hline
\end{tabular}

${ }^{\mathrm{a}}$ Grubbs' catalyst $=\left(\left(\mathrm{PCy}_{3}\right)_{2} \mathrm{Cl}_{2} \mathrm{Ru}=\mathrm{CH}-\mathrm{Ph}\right) .{ }^{\mathrm{b}}$ Unpublished results.

Next, macrocycle 1b was treated with a catalytic amount of cyclopentadienylcobalt dicarbonyl $\left(\mathrm{CpCo}(\mathrm{CO})_{2}\right)$. The utility of the $\mathrm{CpCo}(\mathrm{CO})_{2}$ system as a catalyst for this chemistry was initially revealed by Vollhardt [1]. When the reaction was run with a $5 \%$ molar of $\mathrm{CpCo}(\mathrm{CO})_{2}$ in $n$-decane at $140{ }^{\circ} \mathrm{C}$ for 3.5 hours a $44 \%$ yield of compound $46 \mathrm{~b}$ was obtained (Entry 6, Table 1). Using a stoichiometric amount of the cobalt complex, the yield of $\mathbf{4 6 \mathbf { b }}$ was improved to $88 \%$ (Entry 7 , Table 1). Since stoichiometric quantities of $\mathrm{Co}^{\mathrm{I}}$ complex were still required to obtain high yields, we turned our attention to other transition metal complexes. Ruthenium complexes such as Grubbs' catalyst have been used as catalysts for the cyclotrimerization of alkynes [50-52]. Macrocycles $\mathbf{1 b}$ and 1d were treated with a catalytic amount of bis(tricyclohexylphosphane)benzylidene ruthenium(II) dichloride in refluxing toluene to afford the corresponding triazatrindanes $\mathbf{4 6 b}$ and $\mathbf{4 6 d}$ in moderate yields (36\% and $42 \%$, respectively) (Entries 8 and 9, Table 1). In the case of macrocycle 1b, 20\% of Grubbs' catalyst was also tested, but the yield of $\mathbf{4 6} \mathbf{b}$ did not improve (Entry 10, Table 1). On the other hand, rhodium 
complexes, such as Wilkinson's catalyst [53-55], are also known to be effective for the synthesis of polysubstituted benzenes from alkynes [1-13]. Since chlorocarbonylbis(triphenylphosphane)rhodium(I) was available in our laboratory, this was tested in macrocycle 1a. Using catalytic amounts of $\mathrm{RhCl}(\mathrm{CO})\left(\mathrm{PPh}_{3}\right)_{2}(5 \%$ molar$)$ in toluene at $65^{\circ} \mathrm{C}$, compound 46a was obtained in $88 \%$ yield (Entry 11 , Table 1). Similarly, the cycloisomerization of macrocycles $\mathbf{1 b}$ and $\mathbf{1 d}$ was run and in both cases the yields were high (Entries 12 and 13, Table 1). An attempt to reduce the catalytic amount of $\operatorname{Rh}(\mathrm{I})$ complex to $1 \%$ molar in the cycloaddition of $\mathbf{1 b}$ did not prove to be as successful as when using $5 \%$ molar. After three days, the yield of $\mathbf{4 6 b}$ was $80 \%$ and a $17 \%$ yield of starting material was recovered (Entry 14, Table 1). Wilkinson's catalyst is also highly active for these macrocyclic systems and in the case of macrocycle 1a, the reaction took place at room temperature using a 10\% molar of the complex (Entry 15, Table 1). These results led us to conclude that rhodium is the most suitable of the transition metals tested as it permitted us to work with catalytic quantities and mild reaction conditions. We therefore used this metal preferentially in later experiments.

The next step in our investigation was to study the effect of slight structural variations on the macrocycle scaffold. The incorporation of a methyl group in the propargylic position (macrocycle 2) did not seem to encumber the reaction. The reaction was run in toluene at room temperature for 26 hours giving a $91 \%$ yield (Entry 16, Table 1). By heating the reaction to $60{ }^{\circ} \mathrm{C}$ for 24 hours this yield was improved to $99 \%$. (Entry 17, Table 1). In the case of 16-membered azamacrocycle 3 it was necessary to heat the reaction to $90{ }^{\circ} \mathrm{C}$ to obtain an $81 \%$ yield of $\mathbf{4 8}$, showing that the formation of a 5,5,6-tetrafused structure is more difficult than the formation of 5,5,5-tetrafused system.

Another contribution that we have made in this area is to test other rhodium-based catalytic systems in order to evaluate their efficiency. All of these experiments were performed with macrocycle $\mathbf{1 b}$, whose arylic units of 2,4,6-triisopropylphenyl confer solubility both to the initial macrocycle and the cycloisomerization product (Table 2). Rhodium complexes stabilized by $N$-heterocyclic carbene (NHC) ligands have the advantages of being electronically versatile, easy to handle, and easily synthesized. In addition, unlike rhodium complexes stablized by phosphanes, they are not prone to oxidation and so the reactions can be run in aerobic conditions. Therefore, two rhodium complexes of $\mathrm{N}$-heterocyclic carbenes were also tested for intramolecular [2+2+2] cycloaddition reactions of our closed systems: [RhCl( $\left.\left.{ }^{i} \mathrm{Pr}\right)(\mathrm{cod})\right] \quad\left(\mathrm{I}^{i} \mathrm{Pr}=1,3\right.$-diisopropylimidazolin-2-ylidene, $\operatorname{cod}=1,5-$ cyclooctadiene) and [RhCl(IMes)(cod)] (IMes = 1,3-dimesitylimidazolin-2-ylidene). Macrocycle $\mathbf{1 b}$ was treated with $5 \%$ molar of $\left[\mathrm{RhCl}\left(\mathrm{I}^{i} \mathrm{Pr}\right)(\mathrm{cod})\right]$ in dichloromethane at room temperature to afford a $90 \%$ yield of $\mathbf{4 6 b}$ after 7 days of reaction (Entry 1, Table 2). The reaction time was considerably decreased by switching to toluene and heating at $50{ }^{\circ} \mathrm{C}$ (Entry 2, Table 2). Complex [RhCl(IMes)(cod)] was also able to promote the cycloaddition but needed more vigorous heating (Entry 3, Table 2). This fact may possibly be explained by the greater steric hindrance introduced by the mesityl substituents in the NHC [42].

Another aspect that we investigated was the recovery and reuse of the catalytic system. In collaboration with Muzart et al. we used molten tetra- $n$-butylammonium bromide to see whether this would be an efficient media for the [2+2+2] cycloaddition of macrocycle $\mathbf{1 b}$ that might facilitate the recovery and reuse of the catalyst. Using a 5\% molar of Wilkinson's catalyst, an $80 \%$ yield of $\mathbf{4 6 \mathbf { b }}$ was obtained (Entry 4, Table 2). Furthermore, this molten salt was found to be a good immobilizing agent for the Wilkinson's catalyst enabling recycling. The $\mathrm{Rh}$ complex and $n-\mathrm{Bu}_{4} \mathrm{NBr}$ mixture was dried 
under vacuum and reused although considerably reduced yields were obtained (39\% and $24 \%$ yield in two successive recycles) (Entries 5 and 6, Table 2). With an increase in the initial amount of catalyst to $10 \%$ molar, the result of the first run was similar to that using a 5\% molar (Entry 7, Table 2) although the recycling was more efficient (61\%) (Entry 8, Table 2). In the same molten salt medium we tested $\mathrm{PdCl}_{2}$ as a catalyst. Even though in common organic solvents equimolar amounts of palladium catalyst were required to cyclize triacetylenic azamacrocycles 1 (Entries 1-5, Table 1), we decided to test the catalytic system $\mathrm{PdCl}_{2} / n-\mathrm{Bu}_{4} \mathrm{NBr}$ using only a $10 \%$ molar of $\mathrm{PdCl}_{2}$ at $130{ }^{\circ} \mathrm{C}$ for $24 \mathrm{~h}$. Surprisingly, compound 46b was obtained in an $86 \%$ yield (Entry 9, Table 2) and recycling gave a moderate $36 \%$ yield (Entry 10, Table 2). When this catalytic system was used, palladium nanoparticles were identified by means of transmission electron microscopy (TEM) and energy dispersive X-ray spectroscopy (EDX), which are presumably the active catalytic species [40].

Table 2. Cycloisomerization reactions of macrocycle 1b with different catalytic systems.

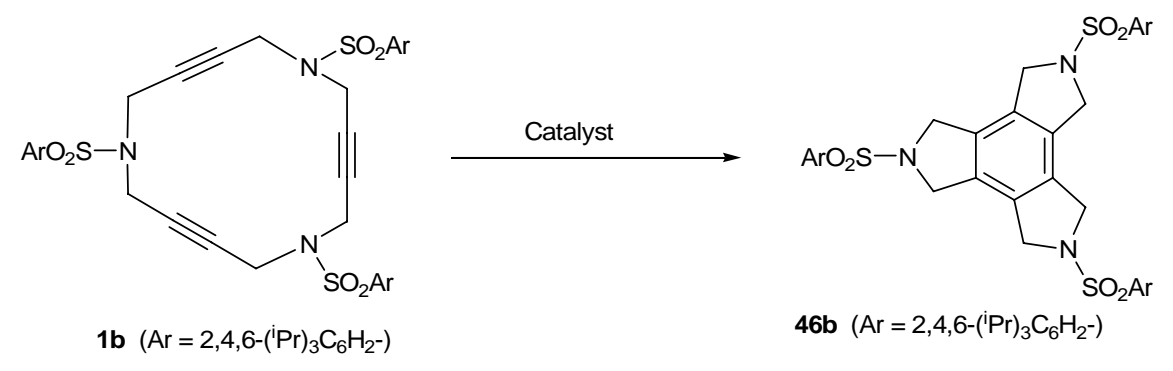

\begin{tabular}{|c|c|c|c|c|}
\hline Entry & $\begin{array}{c}\text { Catalyst } \\
(\% \text { molar })\end{array}$ & Reaction conditions & $\begin{array}{l}\text { Yield of } \\
\text { 46b (\%) }\end{array}$ & Ref. \\
\hline 1 & $\operatorname{RhCl}\left(I^{i} \operatorname{Pr}\right)(\operatorname{cod})^{\mathrm{a}}(5)$ & $\mathrm{CH}_{2} \mathrm{Cl}_{2}$, r.t., $7 \mathrm{~d}$ & 90 & [42] \\
\hline 2 & $\operatorname{RhCl}\left(I^{i} \operatorname{Pr}\right)(\operatorname{cod})^{\mathrm{a}}(5)$ & toluene, $50^{\circ} \mathrm{C}, 48 \mathrm{~h}$ & 98 & [42] \\
\hline 3 & $\mathrm{RhCl}(\mathrm{IMes})(\operatorname{cod})^{\mathrm{b}}(5)$ & toluene, $90^{\circ} \mathrm{C}, 24 \mathrm{~h}$ & 97 & [42] \\
\hline 4 & $\mathrm{RhCl}\left(\mathrm{PPh}_{3}\right)_{3}(5)$ & $n-\mathrm{Bu}_{4} \mathrm{NBr}, 130^{\circ} \mathrm{C}, 7 \mathrm{~h}$ & 80 & [40] \\
\hline 5 & Recycling entry 4 & $24 \mathrm{~h}$ & 39 & [40] \\
\hline 6 & Recycling entry 5 & $24 \mathrm{~h}$ & 24 & [40] \\
\hline 7 & $\mathrm{RhCl}\left(\mathrm{PPh}_{3}\right)_{3}(10)$ & $n-\mathrm{Bu}_{4} \mathrm{NBr}, 130^{\circ} \mathrm{C}, 3 \mathrm{~h}$ & 82 & [40] \\
\hline 8 & Recycing entry 7 & $24 \mathrm{~h}$ & 61 & [40] \\
\hline 9 & $\mathrm{PdCl}_{2}(10)$ & $n-\mathrm{Bu}_{4} \mathrm{NBr}, 130^{\circ} \mathrm{C}, 24 \mathrm{~h}$ & 86 & [40] \\
\hline 10 & Recycling entry 9 & $24 \mathrm{~h}$ & 36 & [40] \\
\hline
\end{tabular}

Wilkinson's catalyst $\left(\mathrm{RhCl}\left(\mathrm{PPh}_{3}\right)_{3}\right)$ was also selected for the cycloisomerization of 20- and 25membered azamacrocyles 22 and 23. When 20-membered macrocycles 22a-c were treated with $\mathrm{RhCl}\left(\mathrm{PPh}_{3}\right)_{3}$ in refluxing toluene, no reaction took place. In all three cases, starting materials together with decomposition products were obtained. A stoichiometric amount of $\mathrm{CpCo}(\mathrm{CO})_{2}$ was also tested. The macrocycle was refluxed in toluene and the solution was heated by light irradiation. However, this reaction also failed and the starting macrocycle was recovered. In the case of the 25-membered ring 23, there are two possible ways of cyclization, namely cycloaddition between three consecutive triple bonds to afford compound $\mathbf{4 9}$ and cycloaddition between non-consecutive triple bonds to afford compound 50. Therefore, when 25-membered macrocycle 23 was treated with a catalytic amount of rhodium complex, the cyclotrimerized compound $\mathbf{4 9}$ resulting from the reaction of 
three contiguous alkynes was obtained as the only product of the process (Scheme 9). The lack of the reactivity of the 20-membered azamacrocycles 22 was explained by DFT calculations [43]. This theoretical study revealed that there are two main factors contributing to the lack of reactivity of the 20-membered macrocycle: firstly, macrocycle 22 has a more stable and delocalized HOMO orbital, and secondly, the formation of a strained ten-membered ring during the cyclotrimerization of 22. These two factors increase the free energy barriers of the rate-determining step and make the intramolecular cyclotrimerization of the 20 -membered azamacrocycles more difficult.

Scheme 9. Cycloaddition of azamacrocycle 23.
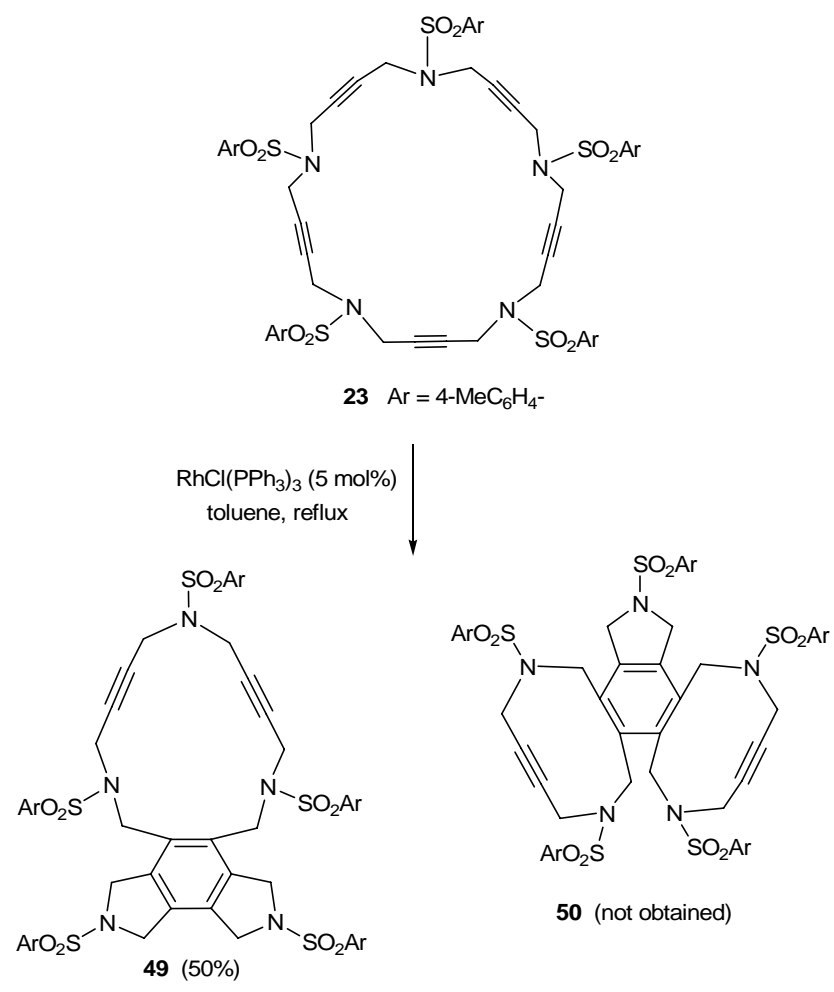

\subsection{Cycloaddition reactions of enediyne azamacrocycles}

Cycloaddition of two molecules of alkyne with an alkene is a straightforward route to substituted cyclohexadiene derivatives, which are important components for Diels-Alder reactions. Therefore, the cycloisomerization of enediyne azamacrocycles opens the door to obtain tetrafused cyclohexadienes with high functionality in a single step. The synthetic versatility of such a transformation becomes more interesting as it proceeds with total stereoselectivity with respect to the stereochemistry of the original double bond of the macrocyclic compound. Given this, we decided to study the cycloisomerization process in the series of enediyne azamacrocycles which we have prepared (29-35 of Figure 3) (Table 3).

The first cases tested were 15-membered macrocycles 29 and $\mathbf{3 0}$ having a trans and a cis olefin respectively. Using a $5 \%$ molar of $\mathrm{RhCl}(\mathrm{CO})\left(\mathrm{PPh}_{3}\right)_{3}$ in toluene at $90{ }^{\circ} \mathrm{C}$ gave high yields of the cycloisomerized compounds 51 and 52 (Entries 1-4, Table 3). No side reactions of the cyclohexadiene system such as aromatization or further cycloadditions took place. The reaction proceeded with total stereoselectivity and initial stereochemistry of the macrocyclic double bond was maintained during the 
cycloaddition process. This experimental finding is consistent with the common mechanism proposed for this kind of cycloadditions in which two alkyne groups undergo initial coupling and subsequent incorporation of the olefin may then occur either by an insertion process or a Diels-Alder reaction.

Table 3. Cycloaddition of enediyne azamacrocycles 29-35.

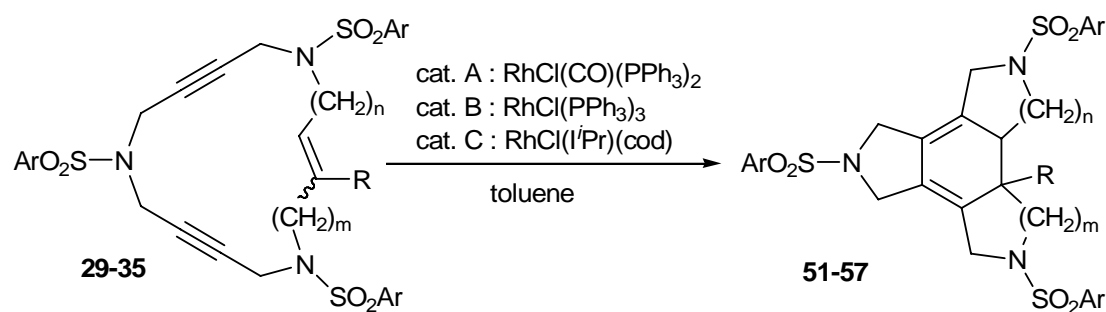

\begin{tabular}{|c|c|c|c|c|c|}
\hline Entry & MCC & Reaction conditions & Product & Yield (\%) & Ref. \\
\hline 1 & 29a & cat. A (5\% molar), $90^{\circ} \mathrm{C}, 24 \mathrm{~h}$ & 51a $\left(\mathrm{Ar}=4-\mathrm{MeC}_{6} \mathrm{H}_{4}^{-}\right)$ & 98 & {$[39,41]$} \\
\hline 2 & 29b & cat. A (5\% molar), $90{ }^{\circ} \mathrm{C}, 24 \mathrm{~h}$ & 51b $\left(\mathrm{Ar}=2,4,6-\left({ }^{\mathrm{i}} \mathrm{Pr}\right)_{3} \mathrm{C}_{6} \mathrm{H}_{2^{-}}\right)$ & 80 & [39] \\
\hline 3 & $30 a$ & cat. A (5\% molar), $90{ }^{\circ} \mathrm{C}, 24 \mathrm{~h}$ & 52a $\left(\mathrm{Ar}=4-\mathrm{MeC}_{6} \mathrm{H}_{4}-\right)$ & 79 & [39] \\
\hline 4 & $30 \mathbf{b}$ & cat. A (5\% molar), $90{ }^{\circ} \mathrm{C}, 24 \mathrm{~h}$ & 52b $\left(\mathrm{Ar}=2,4,6-\left({ }^{\mathrm{i}} \mathrm{Pr}\right){ }_{3} \mathrm{C}_{6} \mathrm{H}_{2^{-}}\right)$ & 68 & [39] \\
\hline 5 & $29 b$ & cat. $\mathrm{B}(5 \%$ molar $), 90{ }^{\circ} \mathrm{C}, 24 \mathrm{~h}$ & $51 \mathbf{b}\left(\mathrm{Ar}=2,4,6-\left({ }^{\mathrm{i}} \mathrm{Pr}\right){ }_{3} \mathrm{C}_{6} \mathrm{H}_{2^{-}}\right)$ & 80 & [39] \\
\hline 6 & $29 b$ & cat. $\mathrm{C}(5 \%$ molar $), 50^{\circ} \mathrm{C}, 3 \mathrm{~d}$ & $51 \mathbf{b}\left(\mathrm{Ar}=2,4,6-\left({ }^{\mathrm{i}} \mathrm{Pr}\right){ }_{3} \mathrm{C}_{6} \mathrm{H}_{2^{-}}\right)$ & 98 & [42] \\
\hline 7 & 31 & cat. B ( $5 \%$ molar), reflux, $24 \mathrm{~h}$ & $p_{2 p-t o y y}$ & 95 & [41] \\
\hline 8 & 32 & cat. B ( $5 \%$ molar), reflux, $24 \mathrm{~h}$ & 2p-toly1 & . & [41] \\
\hline 9 & 33 & cat. $\mathrm{B}(10 \%$ molar $), 80^{\circ} \mathrm{C}, 5 \mathrm{~h}$ & $\int_{3,-10 y}$ & 90 & {$[41]$} \\
\hline 10 & 34 & cat. B ( $10 \%$ molar $), 80^{\circ} \mathrm{C}, 5 \mathrm{~h}$ & 56 & 87 & [41] \\
\hline 11 & 35 & cat. $\mathrm{B}(10 \%$ molar $), 60^{\circ} \mathrm{C}, 4 \mathrm{~h}$ & (2) & 98 & {$[41]$} \\
\hline
\end{tabular}


In order to see whether the Wilkinson's catalyst also promotes the cycloisomerization process, macrocycle 29b was treated with $5 \%$ molar of $\mathrm{RhCl}\left(\mathrm{PPh}_{3}\right)_{3}$ in toluene at $90{ }^{\circ} \mathrm{C}$. Compound $\mathbf{5 1 b}$ was obtained in an $80 \%$ yield, demonstrating that Wilkinson's catalyst exhibits a similar efficiency with respect to $\mathrm{RhCl}(\mathrm{CO})\left(\mathrm{PPh}_{3}\right)_{2}$ (Entry 5, Table 3). Macrocycle 29b was also cycloisomerized using the rhodium-N-heterocyclic carbene complex $\left[\mathrm{RhCl}\left(\mathrm{I}^{i} \mathrm{Pr}\right)(\mathrm{cod})\right]$ which after 3 days at $50{ }^{\circ} \mathrm{C}$ in toluene gave a $98 \%$ yield of $\mathbf{5 1 b}$ (Entry 6, Table 3 ) [42].

The effect of variations on the macrocycle scaffold, either substituents on the double bond or larger cavities, was then tested on the [2+2+2] cycloaddition of enediyne macrocycles. Harsher reaction conditions were required to cycloisomerize macrocyclic enediynes containing a phenyl substituent on the double bond (31 and 32). Refluxing toluene was necessary whereas $90{ }^{\circ} \mathrm{C}$ was sufficient for the non-substituted macrocycles 29 and 30 (Entries 7 and 8, Table 3). In order to study the scope of the methodology, we chose different macrocycles (33, 34 and 35) whose later cycloisomerization led to various fused tetracycles such as 5,5,6- and 5,6,6-ring systems. As a general trend we observed that for enediyne macrocycles, the formation of 5,6,6-membered rings fused to the cyclohexadienic core (product 57) was much faster than the formation of 5,5,6-ring system (products 55 and 56), which in turn was faster than the formation of the 5,5,5-tetrafused structures (products 51 and 52) (Entries 9-11, Table 3) [41]. Although there was a certain tendency to the formation of larger rings, which gave faster reactions, all the macrocycles afforded fused tetracycles unlike in other methods of synthesis, where the failure to construct 5,5,5- has been attributed to ring constraint [56].

The enantioselective cycloaddition of enediynes 29, 31-35 (Figure 3) using a chiral rhodium complex which would lead to chiral cycloadducts was the next aspect to be evaluated. There are only two reported studies of enantioselective cycloaddition of open-chain enediynes using chiral catalysts to afford enantioenriched cyclohexadienes. The two studies used chiral rhodium complexes and the choice of chiral ligands, as well as the nature of the tether between unsaturations, was very important to obtain good yields and high enantiomeric excesses [57,58].

The study of the enantioselective version of the cycloaddition reaction was undertaken with macrocycles 29a and 33 (Table 4). The first chiral rhodium complex tested was the commercially available (bicyclo[2.2.1]hepta-2,5-diene)[2S,3S]-bis(diphenylphosphino)butane rhodium(I) perchlorate. The best reaction conditions found to obtain the high ratio yield/enantiomeric excess was toluene as a solvent at $65^{\circ} \mathrm{C}$ for one day for the two macrocycles 29a (Entry 1, Table 4) and 33 (Entry 2 , Table 4). In the two cases, only moderate enantiomeric excesses were obtained. In order to improve these results, a chiral bidentate ligand, $N$-phosphino tert-butylsulfinamide (PNSO) prepared by Prof. Riera's group was tested in a collaborative study with our own group.

Macrocycle 29a was treated with $\mathrm{N}$-phosphino tert-butylsulfinamide rhodium complex in $\mathrm{CH}_{2} \mathrm{Cl}_{2}$ at room temperature. After $28 \mathrm{~h}$ of reaction the yield of 51a was $77 \%$ and the ee was $48 \%$ (Entry 3, Table 4). When dichloromethane was substituted for toluene the reaction time was reduced considerably from $28 \mathrm{~h}$ to $5.5 \mathrm{~h}$ and a $79 \%$ yield of 51a with a slightly improved $50 \%$ of ee was obtained (Entry 4 , Table 4). The later reaction conditions were applied for macrocycle 33. In this case an excellent yield of $94 \%$ of 55 was obtained although the ee dropped to 7\% (Entry 5, Table 4). The enantiomer formed with the PNSO/Rh complex was the opposite of that obtained in entries 1 and 2. Other experiments using $[\mathrm{RhCl}(\mathrm{COD})]_{2}$ and several chiral phosphines did not lead to better chirality induction than that described in Table 4. 
Table 4. Enantioselective $[2+2+2]$ cycloaddition reactions of $29 a$ and 33 .

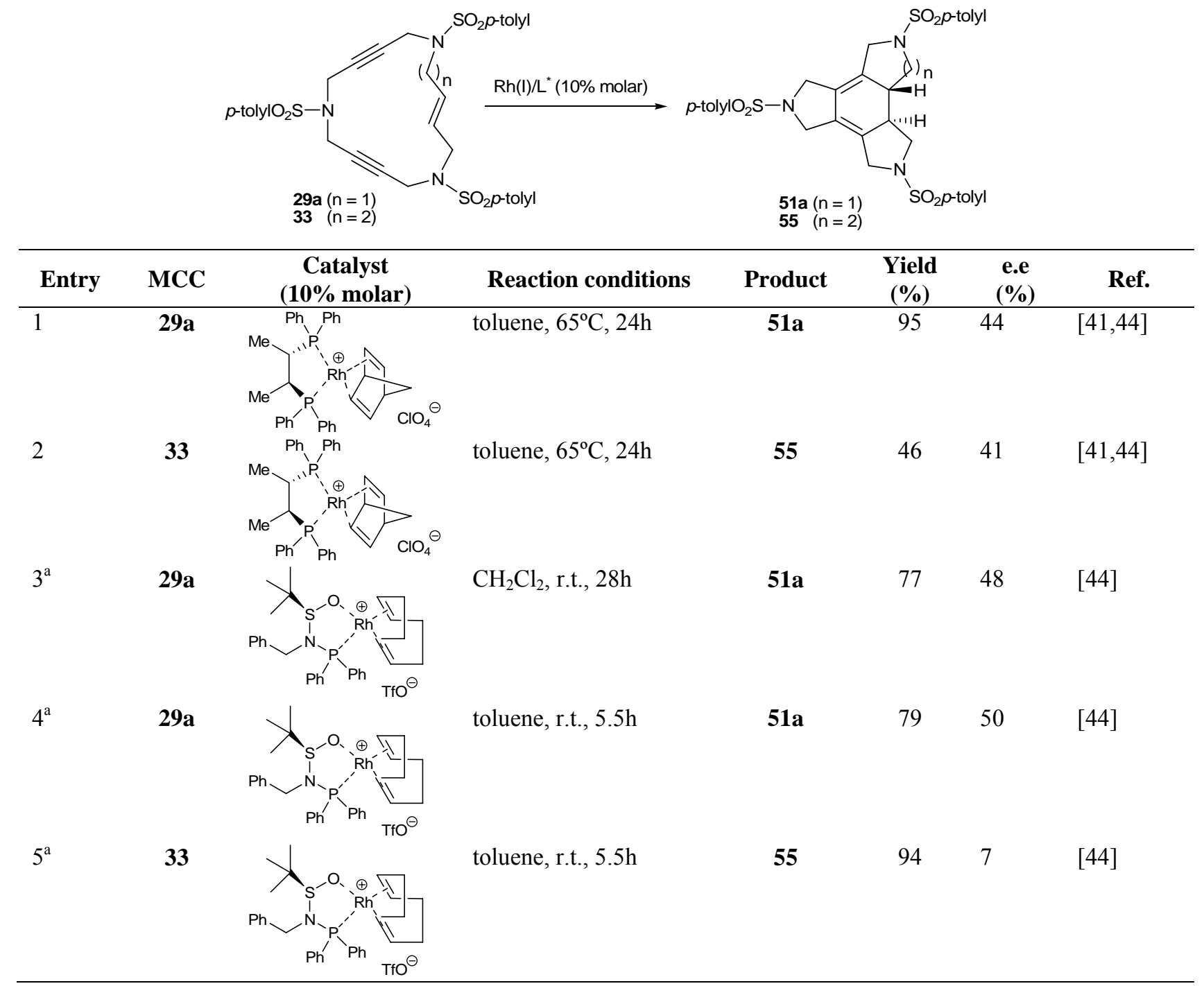

${ }^{\mathrm{a}}$ The enantiomer obtained in these cases was the opposite of that obtained in entries 1 and 2.

3.3. Cycloaddition reactions of triacetylene and enediyne azamacrocycles in the absence of transition metals

The search for new catalysts on the $[2+2+2]$ cycloaddition inside macrocyclic scaffolds has been one of the aims of the present project. During this investigation we found that our macrocyclic systems suffered a thermally induced transformation when the catalyst used was ineffective for the metalcatalyzed $[2+2+2]$ cycloaddition. Three different 15-membered azamacrocycles, namely the triacetylenic 1b, the $(E)$-enediynic 29b and the $(E)$-enediynic bearing a phenyl substituent in the double bond 31, were submitted to the thermal conditions giving rise to new cycloadducts in a stereoselective manner as shown in Scheme 10.

The reaction conditions were varied in order to optimize the process and to find a mechanistic outcome for the overall transformation (Table 5). When the reaction was run without additives, only a moderate yield of the cycloadducts 58 and 59 was obtained after prolonged heating (Entries 1 and 2, Table 5). The yield increased substantially when adding an excess of 1,4-cyclohexadiene (1,4-CHD) 
(Entries 3-5, Table 5) and also moderately when switching the solvent from toluene to chlorobenzene (Entries 6 and 7, Table 5).

Scheme 10. Thermally-induced cycloisomerizations.
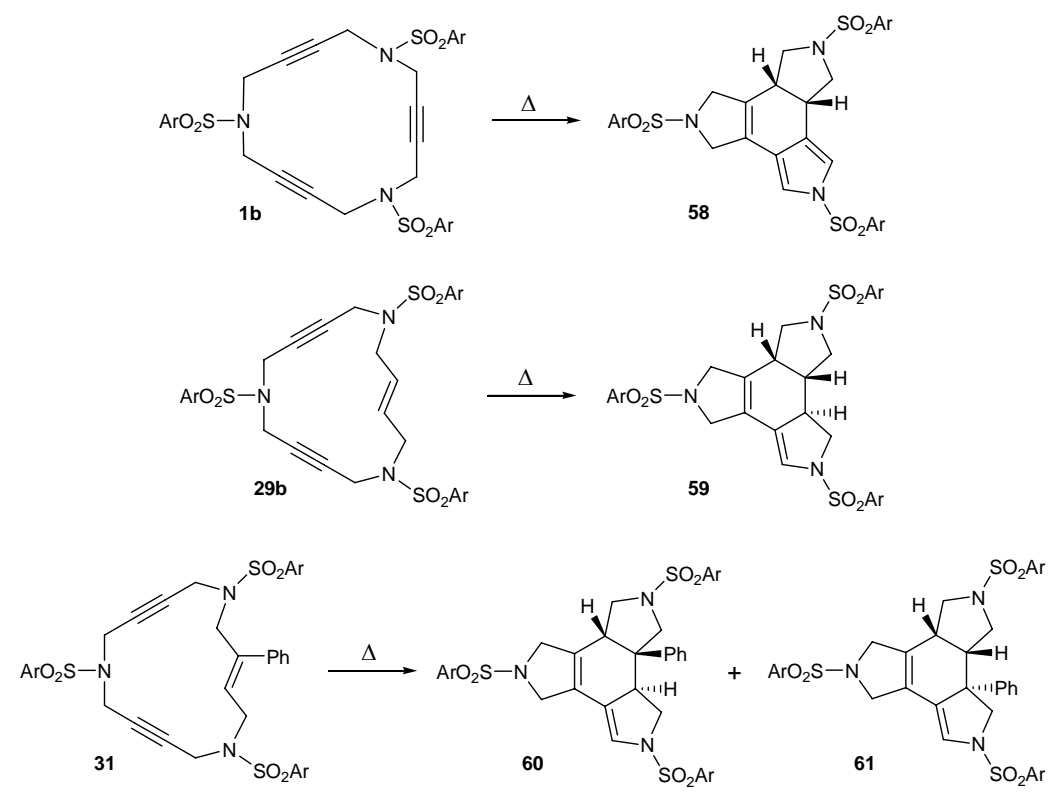

Table 5. Thermal cycloisomerizations of macrocycles $\mathbf{1 b}, \mathbf{2 9 b}$, and 31.

\begin{tabular}{lcllll}
\hline Entry & Substrate & Additive & Reaction conditions & Product & Yield (\%) \\
\hline 1 & $\mathbf{1 b}$ & --- & toluene, $110^{\circ} \mathrm{C}, 30 \mathrm{~h}$ & $\mathbf{5 8}$ & 32 \\
2 & $\mathbf{2 9 b}$ & --- & toluene, $110{ }^{\circ} \mathrm{C}, 6 \mathrm{~d}$ & $\mathbf{5 9}$ & 45 \\
3 & $\mathbf{1 b}$ & $1,4-\mathrm{CHD}$ & toluene, $110^{\circ} \mathrm{C}, 60 \mathrm{~h}$ & $\mathbf{5 8}$ & 77 \\
4 & $\mathbf{2 9 b}$ & $1,4-\mathrm{CHD}$ & toluene, $110^{\circ} \mathrm{C}, 6 \mathrm{~d}$ & $\mathbf{5 9}$ & 78 \\
5 & $\mathbf{3 1}$ & $1,4-\mathrm{CHD}$ & toluene, $110^{\circ} \mathrm{C}, 11 \mathrm{~d}$ & $\mathbf{6 0}+\mathbf{6 1}$ & $81^{\mathrm{a}}$ \\
6 & $\mathbf{1 b}$ & --- & chlorobenzene, $110^{\circ} \mathrm{C}, 30 \mathrm{~h}$ & $\mathbf{5 8}$ & 62 \\
7 & $\mathbf{2 9 b}$ & --- & chlorobenzene, $110^{\circ} \mathrm{C}, 60 \mathrm{~h}$ & $\mathbf{5 9}$ & 60 \\
\hline
\end{tabular}

${ }^{a}$ Combined yield of the two isomers, formed in equimolar quantities.

The role of radical species in the thermal transformation was clarified by means of an EPR study. This showed that benzyl radicals were formed in the cycloaddition in toluene without additives and that these radicals were found to be detrimental to the reaction. Experimental confirmation was obtained by adding benzoyl peroxide, which completely decomposed the starting material. Therefore the addition of radicals neutralizing agents such as 1,4-CHD or the use of a solvent which is less prone to homolytic cleavage such as chlorobenzene led to yield enhancement.

A mechanistic proposal was made for the process based on a tandem intramolecular ene/DielsAlder reaction (Scheme 11). The first step, an ene reaction which affords a vinylallene intermediate 62 , is followed up with a Diels-Alder reaction with the third unsaturation. If this is a triple bond (62a), the Diels-Alder reaction gives a 1,4-cyclohexadiene (63a) which suffers a proton rearrangement to yield 58. If the third unsaturation is a double bond (62b), the Diels-Alder reaction directly yields 59. In the case of 31, the same mechanism accounts for the two products 60 and $\mathbf{6 1}$, each arising from one of the two unequivalent alkynes participating as the ene or enophyle in the reaction. The proposed mechanism was backed up by DFT calculations which gave barriers that were confirmed 
experimentally by differential scanning calorimetry (DSC) analysis [59]. This mechanistic proposal has served as a model for Danheiser et al. $[60,61]$ in their thermally induced intramolecular $[2+2+2]$ cycloaddition reactions of triynes and cyanodiynes.

Scheme 11. Mechanistic proposal for the thermally induced process.

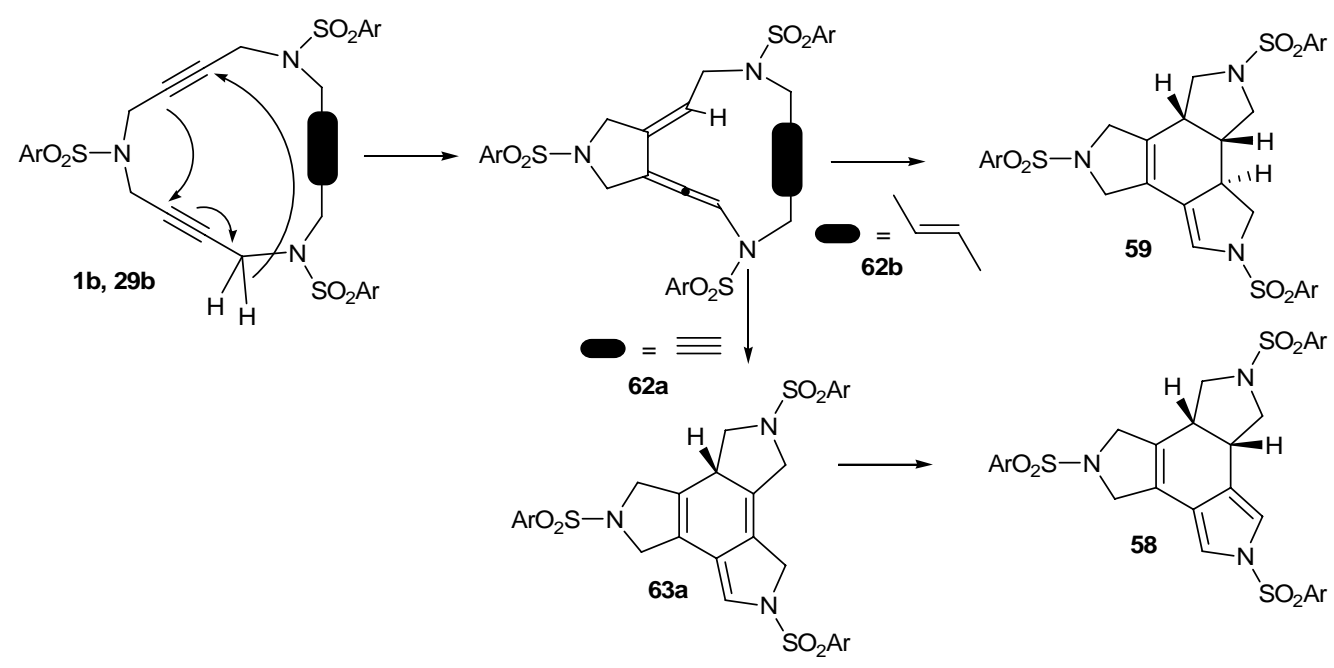

\section{Concluding Remarks}

The $[2+2+2]$ cycloaddition reaction is a powerful tool to construct complex molecules in a one-step, atom economical procedure. The present work clearly shows the potential for this transformation inside macrocyclic scaffolds which give rise to fused tetracycles in a highly efficient manner. Various synthetic routes leading to aza-containing polyalkyne and enediyne macrocycles have been presented. The effectiveness of the cycloaddition reaction has been shown to be dependant not only on the nature of the catalyst system, but also on the size and morphology of the macrocycle. Furthermore, the mechanistic proposal for a thermally induced cycloisomerization which is not catalyzed by metals but that can also take place in the macrocycles has been described.

\section{Acknowledgements}

Continuous financial support has been obtained from the Spanish Ministry of Science and Innovation (MICINN) and from the Generalitat de Catalunya. The most recent financed projects are CTQ2008-05409-C02-02 and 2009SGR637. We would like to thank the contribution made by our PhD students to this research project. Collaborations with the groups of Jacques Muzart in Reims and Antoni Riera in Barcelona have included the interchange of predoctoral students between the two groups.

\section{References and Notes}

1. Vollhardt, K.P.C. Cobalt-mediated [2+2+2]-cycloadditions: A maturing synthetic strategy [New Synthetic Methods (43)]. Angew. Chem. Int. Ed. Engl. 1984, 23, 539-556.

2. Schore, N.E. Transition metal-mediated cycloaddition reactions of alkynes in organic synthesis. Chem. Rev. 1988, 88, 1081-1119. 
3. Lautens, M.; Klute, W.; Tam, W. Transition metal-mediated cycloaddition reactions. Chem. Rev. 1996, 96, 49-92.

4. Saito, S.; Yamamoto, Y. Recent advances in the transition-metal-catalyzed regioselective approaches to polysubstituted benzene derivatives. Chem. Rev. 2000, 100, 2901-2915.

5. Yamamoto, Y. Recent advances in intramolecular alkyne cyclotrimerization and its applications. Curr. Org. Chem. 2005, 9, 503-519.

6. Kotha, S.; Brahmachary, E.; Lahiri, K. Transition metal catalyzed [2+2+2] ccloaddition and application in organic synthesis. Eur. J. Org. Chem. 2005, 4741-4767.

7. Chopade, P.R.; Louie, J. [2+2+2] Cycloaddition reactions catalyzed by transition metal complexes. Adv. Synth. Catal. 2006, 348, 2307-2327.

8. Gandon, V.; Aubert, C.; Malacria, M. Recent progress in cobalt-mediated [2+2+2] cycloaddition reactions. Chem. Commun. 2006, 2209-2217.

9. Tanaka, K. Cationic rhodium(I)/BINAP-type bisphosphine complexes: versatile new catalysts for highly chemo-, regio-, and enantioselective [2+2+2] cycloadditions. Synlett 2007, 1977-1993.

10. Agenet, N.; Buisine, O.; Slowinski, F.; Gandon, V.; Aubert, C.; Malacria, M. Cotrimerizations of acetylenic compounds. Org. React. 2007, 68, 1-302.

11. Shibata, T.; Tsuchikama, K. Recent advances in enantioselective [2+2+2] cycloaddition. Org. Biomol. Chem. 2008, 6, 1317-1323.

12. Galan, B.R.; Rovis, T. Beyond Reppe: building substituted arenes by [2+2+2] cycloadditions of alkynes. Angew. Chem. Int. Ed. 2009, 48, 2830-2834.

13. Tanaka, K. Transition-metal-catalyzed enantioselective [2+2+2] cycloadditions for the synthesis of axially chiral biaryls. Chem. Asian J. 2009, 4, 508-518.

14. Ojima, I.; Vu, A.T.; McCullagh, J.V.; Kinoshita, A. Rhodium-catalyzed intramolecular silylcarbotricyclization (SiCaT) of triynes. J. Am. Chem. Soc. 1999, 121, 3230-3231.

15. Hoven, G.B.; Efskind, J.; Rømming, C.; Undheim, K. Ru(II)-catalyzed cascade reactions in stereocontrolled construction of rigid as-indacene-bridged bis( $\alpha$-amino acid) derivatives. J. Org. Chem. 2002, 67, 2459-2463.

16. Kinoshita, H.; Shinokubo, H.; Oshima, K. Rhodium-catalyzed [2+2+2] cyclotrimerization in an aqueous-organic biphasic system. J. Am. Chem. Soc. 2003, 125, 7784-7785.

17. Yamamoto, Y.; Arakawa, T.; Ogawa, R.; Itoh, K. Ruthenium(II)-catalyzed selective intramolecular [2+2+2] alkyne cyclotrimerizations. J. Am. Chem. Soc. 2003, 125, 12143-12160.

18. Bong, D.T.-Y.; Chan, E.W.L.; Diercks, R.; Dosa, P.I.; Haley, M.M.; Matzger, A.J.; Miljanic, O.Š.; Vollhardt, K.P.C.; Bond, A.D.; Teat, S.J.; Stanger, A. Syntheses of syn and anti doublebent [5]phenylene. Org. Lett. 2004, 6, 2249-2252.

19. Saino, N.; Kogure, D.; Okamoto, S. Intramolecular cyclotrimerization of triynes catalyzed by Nheterocyclic carbene- $\mathrm{CoCl}_{2} / \mathrm{Zn}$ or $-\mathrm{FeCl}_{3} / \mathrm{Zn}$. Org. Lett. 2005, 7, 3065-3067.

20. Shibata, T.; Tsuchikama, K.; Otsuka, M. Enantioselective intramolecular $[2+2+2]$ cycloaddition of triynes for the synthesis of atropisomeric chiral ortho-diarylbenzene derivatives. Tetrahedron Asymmetry 2006, 17, 614-619.

21. Chouraqui, G.; Petit, M.; Phansavath, P.; Aubert, C.; Malacria, M. From an acyclic, polyunsaturated precursor to the polycyclic taxane ring system: the $[4+2] /[2+2+2]$ and $[2+2+2] /[4+2]$ cyclization strategies. Eur. J. Org. Chem. 2006, 1413-1421. 
22. Tanaka, K.; Sagae, H.; Toyoda, K.; Noguchi, K.; Hirano, M. Enantioselective synthesis of planarchiral metacyclophanes through rhodium-catalyzed alkyne cyclotrimerization. J. Am. Chem. Soc. 2007, 129, 1522-1523.

23. Shibata, T.; Uchiyama, T.; Endo, K. Enantioselective synthesis of chiral tripodal cage compounds by [2+2+2] cycloaddition of branched triynes. Org. Lett. 2009, 11, 3906-3908.

24. Nicolaus, N.; Strauss, S.; Neudörfl, J.-M.; Prokop, A.; Schmalz, H.-G.A. [2+2+2]-Cycloaddition approach toward 6-oxa-allocolchicinoids with apoptosis-inducing activity. Org. Lett. 2009, 11, 341-344.

25. Songis, O.; Mísek, J.; Schmid, M.B.; Kollárovic, A.; Stará, I.G.; Saman, D.; Císarová, I.; Starý, I. A Versatile synthesis of functionalized pentahelicenes. J. Org. Chem. 2010, 75, 6889-6899.

26. Severa, L.; Adriaenssens, L.; Vávra, J.; Saman, D.; Císarová, I.; Fiedler, P.; Teplý, F. Highly modular assembly of cationic helical scaffolds: rapid synthesis of diverse helquats via differential quaternization. Tetrahedron 2010, 66, 3537-3552.

27. Sternberg, E.D.; Vollhardt, K.P.C. Cobalt-mediated [2+2+2] cycloadditions en route to natural products: A novel total synthesis of steroids via the one-step construction of the B,C,D framework from an A-ring precursor. J. Org. Chem. 1982, 47, 3447-3453.

28. Yamamoto, Y.; Kuwabara, S.; Ando, Y.; Nagata, H.; Nishiyama, H.; Itoh, K. Palladium(0)catalyzed cyclization of electron-deficient enynes and enediynes. J. Org. Chem. 2004, 69, 6697-6705.

29. Schelper, M.; Buisine, O.; Kozhushkov, S.; Aubert, C.; de Meijere, A.; Malacria, M. Cobalt(I)mediated intramolecular $[2+2+2]$ cocyclizations of (methylenecyclopropyl)diynes as an easy access to cyclopropanated oligocycles. Eur. J. Org. Chem. 2005, 3000-3007.

30. Bennacer, B.; Fujiwara, M.; Lee, S.-Y.; Ojima, I. Silicon-initiated carbonylative carbotricyclization and $[2+2+2+1]$ cycloaddition of enediynes catalyzed by rhodium complexes. J. Am. Chem. Soc. 2005, 127, 17756-17767.

31. Kaloko, J.J.; Teng, Y.-H.G.; Ojima, I. One-step formation of fused tetracyclic skeletons from cyclohexene-diynes and carbon monoxide through $\mathrm{Rh}(\mathrm{I})$-catalyzed $[2+2+2+1]$ cycloaddition reaction. Chem. Commun. 2009, 4569-4571.

32. Geny, A.; Gaudrel, S.; Slowinski, F.; Amatore, M.; Chouraqui, G.; Malacria, M.; Aubert, C.; Gandon, V. A straightforward procedure for the [2+2+2] cycloaddition of enediynes. Adv. Synth. Catal. 2009, 351, 271-275.

33. Jones, A.L.; Snyder, J.K. Intramolecular rhodium-catalyzed [2+2+2] cyclizations of diynes with enones. J. Org. Chem. 2009, 74, 2907-2910.

34. Barkovich, A.J.; Vollhardt, K.P.C. 1,5,9-Cyclododecatriyne. Synthesis and conversion to intermediate 1,2:3,4:5,6-tricyclobutabenzene. J. Am. Chem. Soc. 1976, 98, 2667-2668.

35. Sakurai, H.; Nakadaira, Y.; Hosomi, A.; Eriyama, Y.; Hirama, K.; Kabuto, C. Intramolecular cyclotrimerization of macrocylic and acyclic triynes with group 6 metal carbonyls. The formation of fulvene and benzene. J. Am. Chem. Soc. 1984, 106, 8315-8316.

36. Sakurai, H. Novel $\pi$-electron systems derived from silicon-containing macrocyclic polyacetylenes. Pure Appl. Chem. 1996, 68, 327-333. 
37. Ebata, K.; Matsuo, T.; Inoue, T.; Otsuka, Y.; Kabuto, C.; Sekiguchi, A.; Sakurai, H. Intramolecular oligomerization of disialkylene $\left\{-\mathrm{Me}(2) \mathrm{Si}\left(\mathrm{CH}_{2}\right)(\mathrm{n}) \mathrm{SiMe}(2)\right\}$ bridged cyclic triacetylenes. Chem. Lett. 1996, 1053-1054.

38. Pla-Quintana, A.; Roglans, A.; Torrent, A.; Moreno-Mañas, M.; Benet-Buchholz, J. Synthesis of nitrogen-containing 15-membered triacetylenic macrocycles. Stable complex with Palladium(0). Organometallics 2004, 23, 2762-2767.

39. Torrent, A.; González, I.; Pla-Quintana, A.; Roglans, A.; Moreno-Mañas, M.; Parella, T.; BenetBuchholz, J. Transition metal-mediated intramolecular [2+2+2] cycloisomerizations of cyclic triynes and enediynes. J. Org. Chem. 2005, 70, 2033-2041.

40. González, I.; Bouquillon, S.; Roglans, A.; Muzart, J. Palladium and rhodium-catalyzed intramolecular $[2+2+2]$ cycloisomerizations in molten tetrabutylammonium bromide. Tetrahedron Lett. 2007, 48, 6425-6428.

41. Brun, S.; Garcia, L.; González, I.; Torrent, A.; Dachs, A.; Pla-Quintana, A.; Parella, T.; Roglans, A. Fused tetracycles with a benzene or cyclohexadiene core: [2+2+2] cycloadditions on macrocyclic systems. Chem. Commun. 2008, 4339-4341.

42. González, I.; Pla-Quintana, A.; Roglans, A. Rhodium N-heterocyclic carbene complexes as effective catalysts for [2+2+2]-cycloaddition reactions. Synlett 2009, 2844-2848.

43. Dachs, A.; Torrent, A.; Roglans, A.; Parella, T.; Osuna, S.; Solà, M. Rhodium(I)-catalysed intramolecular [2+2+2] cyclotrimerisations of 15-, 20- and 25-membered azamacrocycles: experimental and theoretical mechanistic studies. Chem. Eur. J. 2009, 15, 5289-5300.

44. Brun, S.; Parera, M.; Pla-Quintana, A.; Roglans A.; León, T.; Achard, T.; Solà, J.; Verdaguer, X.; Riera A. Chiral $N$-phosphino sulfinamide ligands in rhodium(I)-catalyzed $[2+2+2]$ cycloaddition reactions. Tetrahedron 2010, 66, 9032-9040.

45. Moreno-Mañas, M.; Pleixats, R.; Roglans, A.; Sebastián, R.M.; Vallribera, A. 15-Membered triolefinic macrocycles, their coordination chemistry with transition metals, and the catalytic properties of their palladium metal complexes. A review. ARKIVOC 2004, (iv), 109-129.

46. Moreno-Mañas, M.; Pleixats, R.; Sebastián, R.M.; Vallribera, A.; Roglans, A. Organometallic chemistry of 15 -membered tri-olefinic macrocycles: catalysis by palladium( 0$)$ complexes in carbon-carbon bond-forming reactions. J. Organomet. Chem. 2004, 689, 3669-3684.

47. Compounds of type $\mathbf{2 1}$ were prepared by alkylation of the corresponding sulfonamide with an excess of dihalo-2-butyne (4 equiv.).

48. Negishi, E.-I.; Harring, L.S.; Owczarczyk, Z.; Mohamud, M.M.; Ay, M. Cyclic cascade carbopalladation reactions as a route to benzene and fulvene derivatives. Tetrahedron Lett. 1992, 33, 3253-3256.

49. Yamamoto, Y.; Nagata, A.; Nagata, H.; Ando, Y.; Arikawa, Y.; Tatsumi, K.; Itoh, K. Palladium(0)-catalyzed intramolecular [2+2+2] alkyne cyclotrimerizations with electron-deficient diynes and triynes. Chem. Eur. J. 2003, 9, 2469-2483.

50. Peters, J.-U.; Blechert, S. Ruthenium-catalysed conversion of triynes to benzene derivatives - a novel metathesis cascade. Chem. Commun. 1997, 1983-1984.

51. Das, S.K.; Roy, R. Mild ruthenium-catalyzed intermolecular alkyne cyclotrimerization. Tetrahedron Lett. 1999, 40, 4015-4018. 
52. Witulski, B.; Stengel, T.; Fernández-Hernández, J.M. Chemo- and regioselective crossed alkyne cyclotrimerisation of 1,6-diynes with terminal monoalkynes mediated by Grubbs' catalyst or Wilkinson's catalyst. Chem. Commun. 2000, 1965-1966.

53. Grigg, R.; Scott, R.; Stevenson, P. Rhodium catalysed [2+2+2] cycloadditions of acetylenes. Tetrahedron Lett. 1982, 23, 2691-2692.

54. Grigg, R.; Scott, R.; Stevenson, P. Rhodium-catalysed [2+2+2]-cycloadditions of acetylenes. $J$. Chem. Soc. Perkin Trans 1 1988, 1357-1364.

55. Müller, E. The diyne reaction of 1,4-, 1,5-, 1,6-, and 1,7-diynes via transition metal complexes to new compounds. Synthesis 1974, 761-774.

56. Ma, S.; Ni, B. Intramolecular triple Heck reaction. An efficient entry to fused tetracycles with a benzene core. J. Org. Chem. 2002, 67, 8280-8283.

57. Shibata, T.; Kurokawa, H.; Kanda, K. Enantioselective intramolecular [2+2+2] cycloaddition of enediynes for the synthesis of chiral cyclohexa-1,3-dienes. J. Org. Chem. 2007, 72, 6521-6525.

58. Tanaka, K.; Nishida, G.; Sagae, H.; Hirano, M. Enantioselective synthesis of $C_{2}$-symmetric dimethyl cyclohexadienedicarboxylates through cationic rhodium(I)/modified-BINAP-catalyzed [2+2+2] cycloadditions. Synlett 2007, 1426-1430.

59. González, I.; Pla-Quintana, A.; Roglans, A.; Dachs, A.; Solà, M.; Parella, T.; Farjas, J.; Roura, P.; Lloveras, V.; Vidal-Gancedo, J. Ene reactions between two alkynes? Doors open to thermally induced cycloisomerization of macrocyclic triynes and enediynes. Chem. Commun. 2010, 46, 2944-2946.

60. Robinson, J.M.; Sakai, T.; Okano, K.; Kitawaki, T.; Danheiser, R.L. Formal [2+2+2] cycloaddition strategy based on an intramolecular propargylic ene reaction/Diels-Alder cycloaddition cascade. J. Am. Chem. Soc. 2010, 132, 11039-11041.

61. Sakai, T.; Danheiser, R.L. Cyano Diels-Alder and cyano ene reactions. Applications in a formal $[2+2+2]$ cycloaddition strategy for the synthesis of pyridines. J. Am. Chem. Soc. 2010, 132, 13203-13205.

(C) 2010 by the authors; licensee MDPI, Basel, Switzerland. This article is an open access article distributed under the terms and conditions of the Creative Commons Attribution license (http://creativecommons.org/licenses/by/3.0/). 